\title{
THE SYSTEM PARADIGM REVISITED
}

\author{
CLARIFICATION AND ADDITIONS \\ IN THE LIGHT OF EXPERIENCES IN THE POST-SOCIALIST REGION
}

\author{
János KORNAI
}

(Received: 11 October 2016; revision received: 25 October 2016)

\begin{abstract}
The term paradigm was introduced to the philosophy of science by Thomas Kuhn - he used this term to denote the specific approach applied by a school of reasearch to examine its subject matter. Researchers using the same paradigm seek answers to similar questions, and employ similar methods and concepts. In an article published in 2000, the author of this essay introduced the term system paradigm, which focuses on the systems functioning in a society. This study develops the theoretical considerations outlined in that earlier article on the basis of experience on post-socialist transition. The first part compares the socialist and capitalist systems, describing their main characteristics, and concludes that the capitalist system has become established in former socialist countries, except for North Korea and Cuba. The second part analyzes varieties of capitalism within a typology which classifies prevailing forms of politics and government. Three markedly different types are identified: democracy, autocracy, and dictatorship. Huntington wrote about the "third wave" of democratization. This study concludes the third wave has dried up: for the 47 post-socialist countries, only a tenth of the population live in democracy, while autocracy or dictatorship prevails in all other countries in this group. The third part of this essay applies the conceptual and analytical apparatus to Hungary, where capitalism exists, and autocracy is the prevailing politico-governmental form - here we can find important characteristics common to other capitalist countries or other autocracies. This finding is compatible with the observation that there are some, less fundamental, characteristics unique to Hungary, or "Hungarica", which differ from the characteristics of all other countries. ${ }^{1}$
\end{abstract}

Keywords: autocracy, democracy, capitalist system, socialist system, post-socialist transition, Hungary

JEL classification indices: B4, P1, P2, P3, P5

1 Let me express my gratitude here first of all to my wife, Zsuzsa Dániel, who encouraged me to write this study despite all hardships; she was the first reader of several earlier drafts, supporting my progress with several thoughtful suggestions. I also owe my thanks to all the people who read the manuscript and supported me with their recommendations, helped me to collect data and explore the literature. I would like to emphasize Ádám Kerényi's role, who helped me most with his initiatives and exceptional working capacity. It would be really hard to compare the invaluable support from the other contributors, therefore I simply list their names: Dóra Andrics, Réka Branyiczki, Rita Fancsovits, Péter Gedeon, Péter Mihályi, Quang A. Nguyen, Ildikó Pető, Andrea Reményi, Eszter Rékasi, Miklós Rosta, András Simonovits, Ảdám Szajkó, Zoltán Sz. Bíró, Judit Ványai and Chenggang Xu. I am grateful to Brian McLean, my friend and permanent translator for many decades, for the faithful and well readable translation. I would also like to thank Corvinus University of Budapest for providing me the conditions of undisturbed work and "By Force of Thought" Foundation for its contribution to research funding.

János Kornai, Professor Emeritus at Harvard University and Corvinus University of Budapest. E-mail: janos.kornai@uni-corvinus.hu 


\section{INTRODUCTION}

What prompted this study? What type of readers am I addressing? My prime motivation in my academic life has been to discover what kind of society we live in, what its characteristics may be. As any researcher does, I have taken a conceptual apparatus and methodology as a point from which to view my subject matter. Still, as most researchers, I have rarely chosen the method itself, the outlook or approach driving my research, as the subject of a separate paper. The primary aim of my article "The System Paradigm" (Kornai 2000) was to summarize my principles in the theory of science. Seventeen years have passed since and I have been much influenced by new experiences: the changes that have occured in China, the consolidation of the Putin regime, and most strongly of all, the events in Hungary under the political group headed by Viktor Orbán, the prime minister since the election in 2010. It is high time to review the conceptual framework, along with some other matters underlying comparative systems theory.

This study is intended above all for past and future readers studying my works, whether many or few. Apart from them, I target researchers into comparative economics, comparative political science and comparative sociology, and historians of the present-day period; researchers working at universities, research institutes, international bodies, financial institutions, and think tanks, or more specifically, those who professionally analyze the changes occurring in the post-socialist region.

One aim is to sum up, more thoroughly than my first study of the system paradigm did, some elements of my conceptual and analytical apparatus. I do not offer a survey of the literature on the problem. Were I to do so I would need to deal proportionately with views, concepts and methodological principles I agree with, and those I consider incorrect. I am not setting out to do that, I am simply setting out to describe my own paradigm. I mention others' works only if I wish to stress my agreement with them, or the fact of adopting something from theirs into my own thinking - or if I dispute their statements. In that sense the study is not balanced or impersonal, and cannot be so. ${ }^{2}$

Although these aims have motivated me, I hope the study will go beyond my message concerning the theory of science, and as a side-product assist the reader in understanding some major phenomena of our time. For example, Huntington spoke of democracy's "third wave" (Huntington 1991). Where has it gone? Is it

2 With most subjects it is thought immodest for authors to quote their own works repeatedly and thus to crowd the bibliography, but many such references are inevitable if the subject is an author's own work. This study is aimed primarily at those who have read my works, whom I am trying to assist in the "maintenance" of their ideas evoked by those works. 
moving on or has it retreated? Or what place does Viktor Orbán's Hungary hold in comparative systems theory? Is it a specific Hungarian model, a "Hungaricum," or does it have close or distant relatives? ${ }^{3}$

\section{THE CAPITALIST VERSUS THE SOCIALIST SYSTEM}

\section{System}

The word "system" in everyday language and in many sciences occurs in several different senses, from the universe to living organisms, man-made machinery to various human communities, existing, directly observable systems to notional, intellectual ones. In all cases this term conveys the meaning that several lesser parts form a coherent whole. These parts interact. They are not separate items thrown together, for there are comprehensible relations among them organizing them into a structure. The first part of the study uses the term "system" with two meanings. I compare the socialist and the capitalist systems. On occasions I add an attribute, calling them the two great systems, ${ }^{4}$ but the attribute contains no value judgement: I am not bowing before the greatness of either.

A distinct, specific system may emerge in a country over a shorter or longer period, as far as a distinct combination of forms of political power, dominant ideology, ownership relations, and coordination of social activities are concerned. In this sense it has become customary to refer even colloquially to the Putin system or Orbán system. The use of the word system here has an important clarifying force: it points to the mutual effects of various elements in the public state of affairs, operation of the country, and structure of the machinery of power.

I use the capitalism versus socialism pair of concepts purely in a descriptive, positive sense. I am not referring to an imaginary socialism - not to conditions that socialists or communists think should pertain under a socialist system - but to existing socialism (to fall back on an old communist party jargon). Likewise,

3 The term "Hungaricum" was used originally to mark goods which are produced in Hungary and became worldwide known as "Tokaji aszú", a desert wine called 'The King of Wines' already in the Middle Ages, or "barackpálinka", a brandy made from apricot.

4 What I call a great system is related, but not identical, to the Marxist "mode of production" or the neo-Marxist concept of "social formation." I stand aloof from the simplified, primitive theory that political economy lecturers of the socialist period would drum into seminar students, citing in a deterministic, ostensibly "progressive" order of primitive communism, slave-owning society, feudalism, capitalism, and finally, victorious socialism or its full-fledged version, communism. 
I am not examining an imaginary capitalism - not what uncritical devotees of capitalism think should be present - but existing capitalism, as it is.

I obviously did not invent the two terms. Historians of ideas report that both expressions antedate Marx, "capitalism" appearing in Louis Blanc and PierreJoseph Proudhon, and "socialism" in the works of Henri de Saint-Simon. However, they became widespread through Marx's main work Capital (Marx 1867/1990, 1885/1992, 1894/1992), and not simply among Marxists, believers in socialism and antagonists of capitalism. They are used by several moderate or radical opponents of socialism as well, such as Ludwig von Mises and Joseph Schumpeter (Mises 1922/1981; Schumpeter 1942/2010). These days they are heard constantly from politicians and the media, and have been taken up in everyday speech, as well.

However, it must be said that many people avoid this pair of concepts. With "capitalism" there are several reasons. Former reform communists were ashamed to find formations of capitalism appearing out of their efforts. German economic politicians after the Second World War, sensing anti-capitalist feelings among broad swathes of voters, thought it wise to give the long-standing system a new name: "social market economy". ${ }^{5}$ Nor are conservative populists fond of calling their institutional creation capitalism, as they wish to be seen as anti-profit, antibank anti-capitalists.

There are several considerations behind the avoidance of the term "socialist" as well. Marxists reserve the word "communist" for the Marxian vision, where people share goods according to their needs. Existing socialism was seen as a transitional state that would last only until communism appeared. ${ }^{6}$ Meanwhile many Westerners, including politicians, scholars and journalists, referred consistently to the Soviet Union and other countries controlled by communist parties as "communist countries", and do so to this day. The same people would reserve the term "socialist" for the welfare states created by social democratic parties.

It is vital in the theory of science to distinguish sharply between the content of a concept and the name it bears. Many terms in the social sciences and the political sphere have a political slant - associations redolent of value judgements and Weltanschauung. In this respect, it is impossible to reach a consensus on terms.

5 Nowadays, when the use of the term "varieties of capitalism" is widespread, we could say: they wanted to create a variety of capitalism with strong welfare-state characteristics. This intention was inherent in the term "social market economy", dissociating the capitalism of Northern and Western Europe from its Anglo-American counterpart.

6 While the socialist system existed, no country in the bloc ever termed itself communist. That is why I entitled my work The Socialist System, not the "Communist", which many would have recognized more easily. It can be disputed whether the decision was apt, but it left no room for misunderstanding, as I wrote down clearly what I meant by "socialist system" (Kornai 1992). 
My experience, especially in the academic world, is that people cling more tightly to their vocabularies than to the views they express with the words included in those vocabularies. Their compulsive insistence is upon a vocabulary which have been hammered into their heads, or to use a more elegant term, which has become imprinted in their minds by the reading matter and lectures that have affected them most. If that is how it was put by Marx, Max Weber or Polányi (or whoever made the biggest impression on them), it cannot be put otherwise. Or it may happen that the favored term is one they invented themselves and wish to establish as their own terminological innovation.

I abandoned long ago my efforts to end the conceptual confusions. I acknowledged that an absence of conceptual consensus often leads to a dialogue of the deaf. This applies not only to the capitalism versus socialism pair of concepts, but to many other expressions, on which this study touches later (e. g., democracy versus dictatorship). I am attempting only to ensure that readers of my works will understand clearly what one expression or another means in my vocabulary.

\section{Types and their characteristics}

The capitalist system and the socialist system represent two types of socio-political formation in the recent past and in the present.

The creation of a typology is among the major steps in scientific examination. It has played a big part in developing many disciplines (e.g., biology, genetics, medicine, linguistics, cognitive sciences, anthropology or psychology). ${ }^{7}$ A type is a theoretical construct. Actual, individual historical constructs such as Hitler's Germany or Churchill's UK differ from each other in important respects. Nonetheless, I describe, within my own conceptual apparatus, both of them as capitalist countries. Similarly different in their essential characteristics were Stalin's Soviet Union, Kádár's Hungary and Ceaușescu's Romania. Still, I call all three socialist countries. To distinguish the types within a typology calls for describing their characteristics, which may differ sharply. ${ }^{8}$ Here the task is to find the characteristics which, on the one hand, distinguish the two types, the capitalist and socialist systems; and on the other hand, they show what is common to the many individual phenomena ocurring in each country belonging to the same type in a given period.

7 Of special interest are the typologies of modern psychology and the cognitive sciences. Studying these could be very useful to comparative system theory in the social sciences.

8 There are several synonyms for the word "characteristic" in this context: trait, feature or attribute, for example. 
Although a type is a theoretical construct existing only in researchers' minds, it is based on the observation of reality and underlines important common features of past and present structures. Given the specific realizations of the "great system" that vary between countries and periods, the type is created to embody their common characteristics in a theoretical generalization. ${ }^{9}$ So the usable, operable typology is based on observation of the historical reality. Social science distils it from experience.

In the rest of this study I employ the pairs capitalist system/capitalism and socialist system/socialism as synonymous. ${ }^{10}$

In creating types, the method here is to pick out the various characteristics in which each type differs markedly from the others. The aim is not profuse description. On the contrary, it is to grasp the relatively few, highly characteristic, conspicuous features. The best would be to list as few as possible - simply those necessary and sufficient for differentiation. ${ }^{11} \mathrm{I}$ do not claim that the number of such characteristics should be exactly nine; I would be open to altering Table 1 if there were convincing arguments for doing so.

It is essential to list among the characteristics only those that are system-specific. The comparative table should by no means include phenomena which are found frequently in both great systems, important and influential though they may be to the operation of certain institutions or the lives of citizens. For example, repression cannot appear as a system characteristic because it does not appear exclusively under the socialist system. Ruthless examples have occurred and continue to occur under the capitalist system as well: in Hitler's Germany, in Hungary under the Horthy and the Nazi Arrow-Cross regime, Franco's Spain, and many Latin American military dictatorships. Under both systems it may happen that incompetent people gain leading positions. In both, the major economic indicators fluctuate strongly. However great the effects of these phenomena, they are not system-specific.

$9 \quad$ In my phraseology, I employ the unqualified word "type." It has the same meaning as what Max Weber calls an "ideal type" (Weber 1922/2007). Yet I avoid Weber's term, since I find that the attribute "ideal" has a distractingly normative ring. However, Weber too used the expression "ideal type" to denote an abstract theoretical mapping of existing systems.

10 The second term in each pair (capitalism and socialism, respectively) denotes, for many authors, a system of ideas rather than a formation that exists or has existed. It should be clear from the context that I am discussing the latter: "capitalism" denotes the capitalist system as it exists or has existed, "socialism" likewise.

11 Table 1 contains many expressions I have taken over from my earlier works, where I discussed their meanings in detail. They include coordination mechanism, market and bureaucratic coordination, shortage economy, surplus economy, labor shortage, labor surplus, revolutionary innovation, soft and hard budget constraints. For space reasons I cannot go into these again here. 
Table 1. Characteristics of the capitalist and socialist systems

\begin{tabular}{lll}
\hline No. & Capitalist system & Socialist system \\
\hline Primary characteristics & $\begin{array}{l}\text { The ruling political group ensures the } \\
\text { dominance of private property and market } \\
\text { coordination }\end{array}$ & $\begin{array}{l}\text { The ruling political group, i.e., the Commu- } \\
\text { nist Party, enforces the dominance of public } \\
\text { property and bureaucratic coordination } \\
\text { Dominant form of property: state ownership }\end{array}$ \\
$\begin{array}{l}\text { Dominant form of property: private owner- } \\
\text { ship }\end{array}$ & $\begin{array}{l}\text { Dominant form of coordination mechanism: } \\
\text { market coordination }\end{array}$ & $\begin{array}{l}\text { Dominant form of coordination mechanism: } \\
\text { bureaucratic coordination }\end{array}$ \\
\hline $\begin{array}{l}\text { Secondary characteristics } \\
4\end{array}$ & $\begin{array}{l}\text { Surplus economy, i.e., the buyers' market, is } \\
\text { the dominant state of the market for goods }\end{array}$ & $\begin{array}{l}\text { Shortage economy, i.e., the sellers' market, } \\
\text { is the dominant state of the market for } \\
\text { goods and services }\end{array}$ \\
5 & $\begin{array}{l}\text { Labor surplus is the dominant state of the } \\
\text { labor market }\end{array}$ & $\begin{array}{l}\text { Labor shortage is the dominant state of the } \\
\text { labor market }\end{array}$ \\
6 & $\begin{array}{l}\text { Fast technical progress; the system often } \\
\text { generates revolutionary innovation }\end{array}$ & $\begin{array}{l}\text { Slow technical progress; the system rarely } \\
\text { generates revolutionary innovation }\end{array}$ \\
7 & $\begin{array}{l}\text { High income inequality } \\
\text { Hard budget constraint for organizations in }\end{array}$ & $\begin{array}{l}\text { Low income inequality } \\
\text { Soft budget constraint for organizations in a } \\
\text { quite broad sphere } \\
\text { a quite broad sphere }\end{array}$ \\
$\begin{array}{l}\text { Direction of corruption: it is mostly the } \\
\text { seller who bribes the buyer }\end{array}$ & $\begin{array}{l}\text { Direction of corruption: it is mostly the } \\
\text { buyer who bribes the seller }\end{array}$ \\
\hline
\end{tabular}

I do not want to give an impression of exactitude. In describing the characteristics, I have to allow myself to use umbrella terms such as "state ownership" and "private ownership," although I know that both categories can take many different legal forms. ${ }^{12}$ There appear repeatedly in the table words like "dominant" and "largely", without mention of a quantitative value for them. If it is 70 per cent, then it is dominant but if it is 69 per cent, it is not? I content myself with not describing the system in terms of quantification but in a qualitative fashion, and relying on the intuition of those using the conceptual apparatus, in the hope that they will likewise sense the meaning of these inadequately precise words. My professional conscience is quieted by knowing that many scientific typologies do the same. Taking that into account, caution must be shown in using such typologies: there are some analytical tasks to which they are fitted and some to which they are not.

12 The category of state ownership includes both central- and local-government ownership. This needs mentioning as the Hungarian vernacular often inaccurately confines state ownership to central-government ownership. If a school, say, or a hospital passes from local-government into central-government hands, this is labelled "nationalization", while it means only that the execution/implementation of the state's ownership rights has been centralized, important though that change may be as well. 
Another reason I tend to use expressions like "dominant" and "largely" is because I know that there can appear in a given type of country phenomena that differ from, or are even contrary to, the dominant phenomenon. For example, while the Soviet or Polish economy was tormented by the shortage economy there were still unsold goods in the stores and warehouses. In the western world with its typical surplus economy, there are long queues of consumers waiting for tickets to a new and exciting film.

Is there not a discrepancy of size in comparing capitalism, which has been around for centuries and will probably continue to exist for several more, with socialism, which existed historically for only a few decades and then collapsed? Is my reason for bringing the latter up not that I was a citizen under the socialist system for much of my life? I firmly answer both questions in the negative. Now, 25 years after the collapse, I am convinced that such a comparison has great explanatory power. History, at a price of suffering for millions of people, set up a laboratory experiment by bringing into being a system markedly different from capitalism. Comparing them yields a better understanding of what capitalism is. Such randomly generated experiments also teach a lot in other branches of science. Examining the victim of an accident marked an important step in neurology. Part of the patient's brain was damaged and researchers knew precisely which part, and from that they could deduce what functions that part of the brain played.

What is to be understood by a hierarchy of characteristics? How do primary and secondary characteristics differ? ${ }^{13}$ In my line of thought, primary characteristics determine the system as a whole, including secondary characteristics. The joint presence of the primary characteristics is a necessary and sufficient condition for the appearance of the secondary ones. It could also be said that primary characteristics form the minimum conditions for the existence of the capitalist or the socialist system. A sensible first stage when beginning to study a country is to concentrate on these primary characteristics. The results of doing so will then have predictive force. However, the primary characteristics do not generate all the secondary ones in a deterministic way. The effect is stochastic. There is a very good chance of finding the secondary characteristics in a country examined if the primary characteristics have already been identified.

This relationship is shown in Figure 1. The figure shows mutual effects: the primary and secondary characteristics have mutual influences on each other. The thick arrow denotes that the primary characteristics are the decisive ones, and the thin arrow in the opposite direction that the reactive influence is less strong.

13 Basic and fundamental are commonly used synonyms for "primary" in this context. 


\begin{tabular}{|l|l|}
\begin{tabular}{|l|l|} 
Primary characteristics \\
1. Relation of the political \\
coordination mechanisms \\
$\begin{array}{l}\text { 2. Dominant form of property } \\
\text { 3. Dominant coordination mechanism }\end{array}$
\end{tabular} & $\begin{array}{l}\text { Secondary characteristics } \\
\text { 4. Power relations between the two sides } \\
\text { of the market for goods and services } \\
\text { 5. Power relations between the two sides } \\
\text { of the labor market } \\
\text { 6. Speed and qualitative features of } \\
\text { technical progress } \\
\text { 7. Income distribution } \\
\text { 8. Softness/hardness of the budget constraint } \\
\text { 9. Direction of corruption }\end{array}$ \\
\hline
\end{tabular}

Figure 1. Interactions between the primary and secondary characteristics

The expression "decisive," as I have noted already, shows a tendency, not full determination. Many people whose forebears have suffered from heart disease will inherit that susceptibility. But whether the disease actually emerges depends to a large extent on the patients' way of life - if they drink alcohol, smoke, fail to take exercise, or find themselves in stressful situations, they are more likely to suffer acute heart disease than if they live moderate, cautious lives, do sports and live calmly. All socialist systems are inclined to develop a shortage economy, but the intensity of shortage was very strong in the 1980s in the Soviet Union, Poland and Romania, but less so in East Germany (Kornai 1980a, 2014c).

Within the two blocs shown in Figure 1 there are also interactions among the characteristics. To simplify the explanation, these are ignored in the figure and in this textual commentary on it.

\section{Classifying the post-socialist region's countries by the typology of capitalist versus socialist systems}

Let us apply the conceptual apparatus introduced above to the countries which qualified as socialist countries in 1987 (Kornai 1992). Altogether 47 countries belong here; let us call the area they occupied the post-socialist region. ${ }^{14}$ The word

14 Like many authors, I apply the epithet "post-socialist" to the countries that were under the control of the communist party in 1989-90. Here again there appears a conceptual mix-up: many politicians and political analysts apply the labels "post-socialist" or "post-communist", usually with a pejorative ring, to parties that emerged from the former ruling communist party after the change of system, taking over many officials of the previous party and most of its assets. This they do regardless of what changes have occurred in the leadership or membership or in its ideology. 


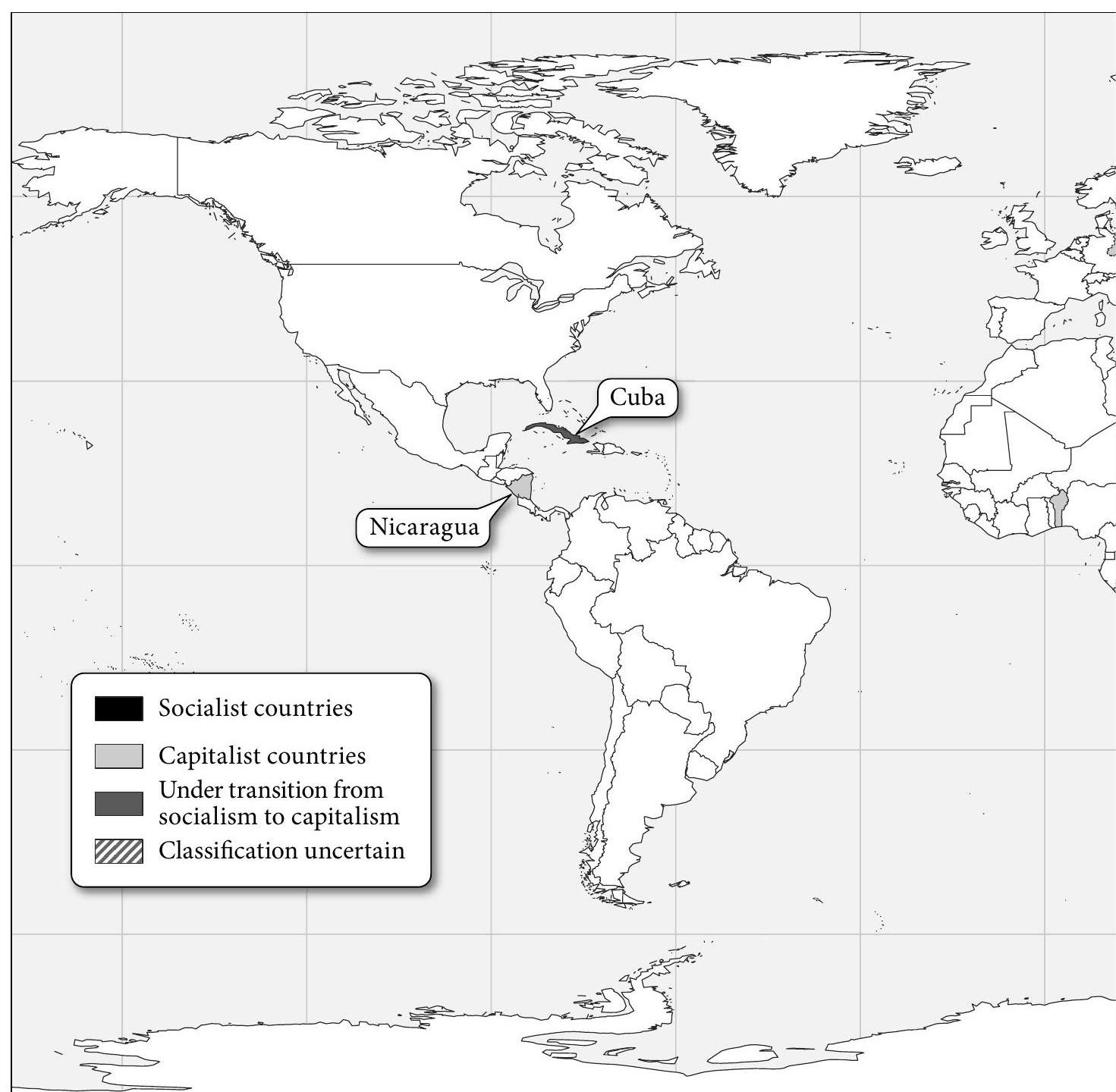

"region" is not applied in a geographical sense, as this is not a group of adjacent countries; most are in Europe and Asia, but some in Africa and Latin America also belong here. ${ }^{15}$

15 A list of the post-socialist countries appears on my website (http://www.kornai-janos.hu/Kornai2016-SP-revisited.html), as Tables 1 and 2 in Background Material 1. 


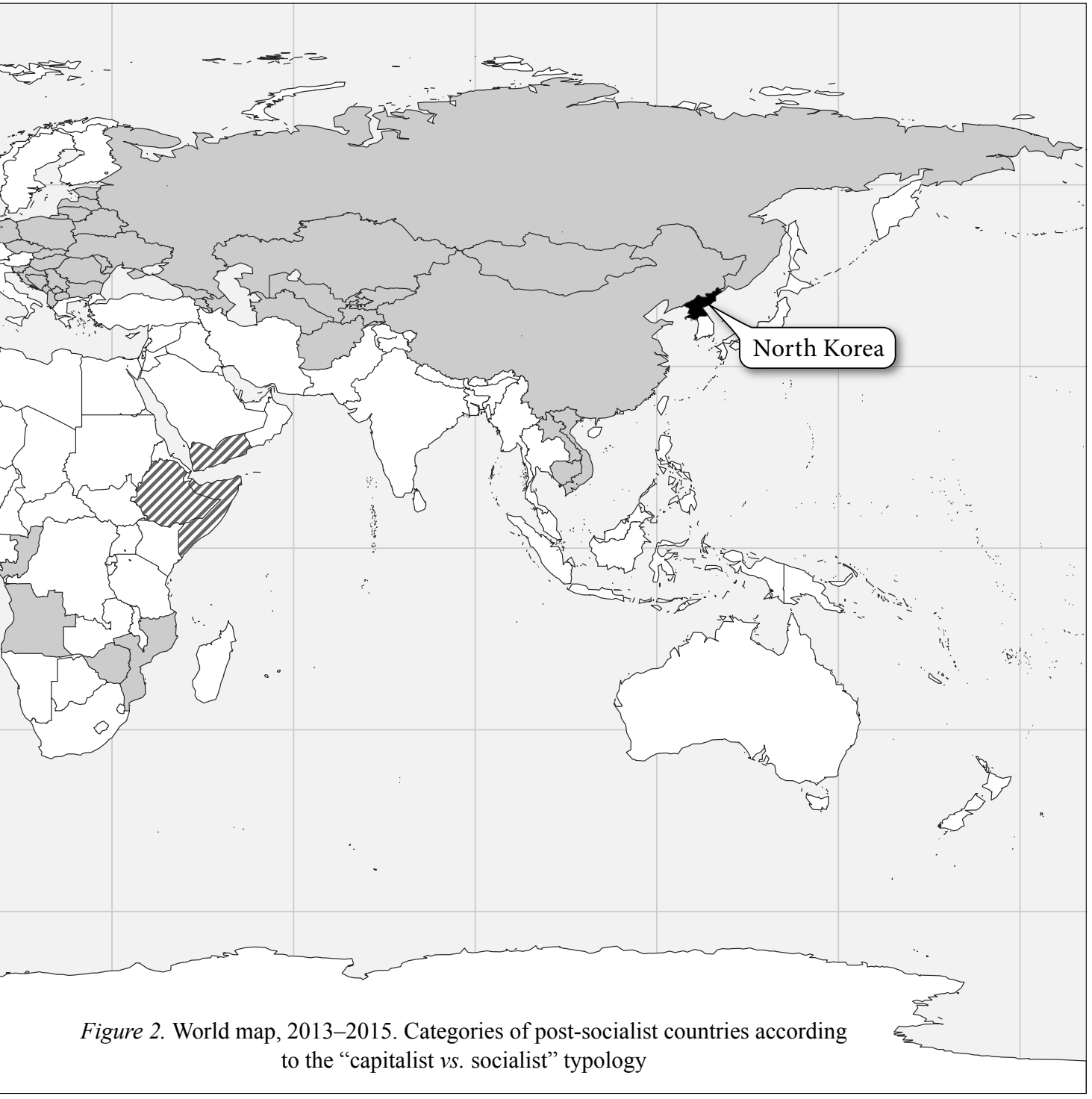

The locations of the post-socialist region on the world map appear in Figure 2. The countries of the post-socialist region are marked with various non-white shades in the figure. The other parts of the world, marked in white, never went through a socialist-system phase of rule by a communist party. 
Rule under the socialist system is marked in black. ${ }^{16}$ The whole region would be black if the map showed the situation in 1987. Now the only spot of black on the world map is the territory of one country, North Korea - a tiny dot on the map of the world. Countries in transition from socialism to capitalism are marked in dark grey. Again, this applies to only one country, Cuba, making a single spot of dark grey at a global scale. Most of the region is colored light grey: these are the countries where the capitalist system operates. ${ }^{17}$

A sizeable part of the region has a diagonally striped pattern. This denotes uncertainty: I am uncertain whether these countries should be marked black, light grey or dark grey.

The sources for placing the countries in these categories are considered again in the comments on another world map (Figure 3). There I will shed light on the relation between the two world maps and the background materials accessible on my website. ${ }^{18}$

There is a broad if not full consensus among experts as to when the change of system occurred in the countries affected. This expression, often used in political jargon and everyday speech, gains considerable content in the conceptual and analytical framework already discussed. With a few exceptions, the countries in the group qualifying as socialist in 1987 all have undergone a transition from socialism to capitalism.

16 Background Material 2, appearing on my website shows the two world maps, Figure 2 and 3, not in black-and-white but in various colors. The colors might help in recognizing the distribution of various types in the region.

17 Empirical support for the classifications would be much clearer if there were reliable statistics on the developments in ownership relations and the spread of the market mechanism. Unfortunately, the data available are only partial and sporadic. All countries prepare statistics on production and added value, broken down by industries, geographical regions, occupations, or output produced, but nowhere do national statistical offices calculate or publish regularly any breakdown of output data by form of ownership, or the proportion of total production sold at administratively set prices. It is surprising to find that only non-state institutions in a handful of countries concern themselves with ownership relations and the radical transformation of coordination mechanisms, although these were among the basic requirements for the change of system. Prestigeous international organizations regularly publish comparative figures on production, foreign trade, or financial affairs, but - in my view - they pay insufficient attention to the transformation of ownership relations and the relative weights of bureaucratic and market coordination.

18 See Background Material 2 and 3 on my website. 


\section{Static representation and the transformations}

Figure 2 presents a still image, as if a snapshot were taken of the world and a specific group of countries within it. The shot shows a static state of the present, but if a motion picture camera were to be used instead, it would show the dynamics of the changes of system as well.

The map conveys the presence of the two systems at a point in history when both are operating according to the characteristics apparent in Table $1 .{ }^{19}$ It does not depict the creation phase of the system. I draw attention to this primarily in connection with Characteristic 1 . The initiatory role in the genesis of the socialist system is played by the political sphere; the communist party makes very rapid moves in historical terms to impose state ownership and centralized bureaucratic coordination on society. By comparison, the transitions in most countries from pre-capitalist forms to the capitalist system were very slow. Initially, the political authorities only tolerated and took advantage of the services and resources of the bourgeoisie. The relation of the political forces to capitalism changed gradually until they had become active defenders of private ownership, market coordination and enforcer of private contract. Different again was the role of the political sphere in the route back after 1989-1990 from socialism towards capitalism, in which the processes of transformation were instigated and headed by the procapitalist political forces.

Only one country in Figure 2 is marked in dark grey, to show that it is in transition from socialism to capitalism. As mentioned before, the one country I put here when writing this study in 2016 was Cuba. Though a member of the Castro family remains at the pinnacle of power, this is no longer the Cuba of Fidel Castro. Cautiously, the country has begun to display the characteristics of capitalism.

To continue the earlier comparison, of using a motion picture camera instead of taking a still image, many more countries would appear as dark grey in the squares representing the 1990s and 2000s. The speed of change and the pace of the transformation of certain characteristics varied from country to country.

Historians and historical recollections like to focus on a particular calendar date for the beginning or end of a historical period. The October Revolution in 1917 Tsarist Russia is often understood to have been started by the blank shot from the Aurora cruiser signalling the attack on the Winter Palace in St. Petersburg. In fact, most period changes are more blurred in time.

Figure 2 shows the world-historical defeat of socialism through the lens of my conceptual apparatus. Three decades earlier, the socialist system prevailed over 34.7 per cent of the world's population and 30.7 per cent of its area (Kornai 
1992). Nowadays, when the socialist system persists only in North Korea, the proportions have shrunk to 0.3 per cent of the population and 0.1 per cent of the area. ${ }^{20}$

\section{The explanatory power of a capitalist-versus-socialist typology}

When examining a complex historico-social phenomenon, it is rare to find a convincing single-factor explanation to account for its appearance and/or long-term duration. Complex phenomena are complex indeed and call for a multi-factor explanation.

Both under capitalism and socialism appear several important complex phenomena, explained by several factors; one of them is the system. I emphasize the word one because not for a moment do I claim that a full explanation of a certain complex phenomenon can be gained by simply pinpointing the great system in which it appears. But there can often be found within a larger ensemble of explanatory factors some that are system-specific. Indeed, one or two may turn out to be the most important elements of explanation. Here are two examples.

One is the speed and quality attributes of technical progress, which is affected by several factors, e. g., the country's level of economic development, the state of its education system, and the size of its state support for research. Alongside these, the system-specific effects are notably important. It can be shown how large numbers of revolutionary innovations have appeared under capitalism, which deeply affect production and people's lives, whereas the socialist system could produce just one outside the arms industry (Kornai 2014c, pp. 3-24). Promising inventions that appeared in a socialist country could find no innovator able to spread it on a mass scale; this function would be usurped by a capitalist innovator instead. One well-known example is Ernő Rubik's invention, Rubik's Cube. In then-socialist Hungary, Rubik had no luck touting his creation round the industrial leaders. Rubik's Cube began its worldwide conquest when its manufacture and mass marketing were taken over by capitalist firms abroad. Even the distribution process for this first pioneering innovation was immeasurably swifter under capitalist conditions than under the socialist system.

The other example is the labor-market situation. Search processes take place under all systems: employees seek employers that meet their needs and vice versa. The search process is accompanied by ubiquitous frictions: everywhere there are temporarily unfilled jobs and ready workers unable to find jobs. This is a complex matter explainable by many concurrent factors. One example is the

20 See Background Material 4 on my website. 
flexibilty of knowledge generated by the education system. Does it facilite quick adjustment to the rapidly changing demand for labor? Other factors include legal contraints on dismissing employees, the effectiveness of labor recruitment agencies, and so on. But some basic explanatory factors are system-specific. What are the general labor-market proportions of supply to demand? Does it tend towards excess supply (capitalism) or excess demand (socialism in its mature, relatively developed stage)? That determines to what extent employees are at the mercy of employers. An employee is under constant threat of dismissal and unemployment, they feel more defenceless than those who find jobs easily. Here we have arrived at deep-rooted system-specific effects, namely the relative power of employers and employees (Kornai 1980, 2014b).

The two examples enhance in a further way the argument for the explanatory power of the capitalism-versus-socialism typology. The nine system-specific factors listed in Table 1 were compiled with a positive approach. They do not reflect the author's desires or choices of values. These are the characteristics of countries considered socialist or capitalist, an observable group from which the list of characteristics in Table 1 can be "distilled." Those who acknowledge this as a positive description, and shift to the normative approach, can append to them their views on the capitalism-versus-socialism pair, based on their own system of values. For my part, I do not reach any summary moral conclusion. By my system of values, dynamism and rapid technical advance form a great virtue in capitalism, but I see the risks and drawbacks of such development. For one, I see the vulnerability of the workforce as a repugnant characteristic of capitalism. As for the socialist system, it did not just have repulsive characteristics. Many of them were attractive: upward social mobility for the poor, some reduction in social distances, and employee security stemming from the labor shortage. The typology described above offers methodological assistance to evaluating the great systems. Value judgments should be based upon considering the whole set of characteristics for the system in question.

It is not unlike the marking system in education. Let us assume that the individual marks reflect each student's attainments. Then it is up to the teachers, the parents, the classmates or the personnel department of a future workplace, to decide what configuration of the marks to take as a basis for forming an opinion of each student: the simple average of the marks, or the mark in some successful subject taken by the evaluator to be the most important. I will return to this question later, but before discussing the value judgements about the great systems, let me present the typology I use for the alternative forms of politics and government. 


\section{VARIETIES OF THE TWO GREAT SYSTEMS, ALTERNATIVE FORMS OF POLITICS AND GOVERNMENT}

\section{The varieties of the great systems}

Although the idea had a long theoretical history behind it, much attention was rightly paid in comparative systems theory to the work of Peter A. Hall and David Soskice on the varieties of capitalism (for their first comprehensive volume of studies, see Hall - Soskice 2001). This was a seminal idea which generated a school of thought: by now it is possible to talk of a broad and viable research program for examining the varieties of capitalism. ${ }^{21}$

Although this ground-breaking work discussed the varieties of the capitalist system only, it can be applied by analogy to those of the socialist system as well. The lively and complex debate that arose before the change of system, about socialism's alternative "economic mechanisms," the various models of socialism, and the many possible forms that reform might take, can certainly be called a discourse on the varieties of socialism, although the word "variety" was not used in this sense. Here I see much of my own work as part of a research program into "varieties of systems," though the works I can list did not use that term before the appearance of the works of Hall and Soskice, or for a long time after. Now, in this study, I too will apply this useful and operable expression.

There are several kinds of criteria on which to base the typology of varieties for each of the great systems. For instance, it is possible to produce a typology whose types represent the characteristic distribution of income and wealth. Another angle would be to measure how much the state intervenes in the operation of the economy and in what ways. Hall and Soskice brought these criteria to the fore in their study, which created and contrasted two main varieties: liberal market economies and coordinated market economies. The prime example of the first is the economy of the United States and of the second that of Germany.

Baumol et al. (2007) employed other criteria in defining types of varieties: whether private initiative and the spirit of enterprise are strong or weak. They therefore named their varieties entrepreneurial capitalism versus oligarchic or state-run capitalism.

Bohle and Greskovits (2012) likewise came up with a new typology: capitalism is neo-liberal or embedded neo-liberal or neo-corporatist.

Acemoglu and Robinson's book (2012) has had great influence. The authors put the exciting question of what explains why some nations fail at a turning

21 The expression "research program" was introduced into the theory of science by Lakatos (1978), and it is used here in the sense applied by Lakatos. 
point and others succeed. They see as the major explanatory factor whether their social organisms are inclusive or exclusive. This is a typology with great explanatory power, although it does not preclude attention to other influential factors as well.

In the rest of this study I use another typology of varieties, not to replace those mentioned but to complement them. The main organizing criterion here is the politico-governmental form. This is not my invention. Both political scientists and political philosophers - beginning with ancient Greek philosophers, continuing with Machiavelli and concluding with present-day researchers - attach huge importance to analysing the alternative forms of political power. This has been seminal throughout in political science and political philosophy. Sadly, the other social sciences, including economics (with estimable exceptions), have largely broken off from political science. My first study entitled "The System Paradigm", appearing in 2000, merely touched on the relations of politics and the economy. The almost two decades since have taught me much, among other things, what a huge effect political structures and political ideas have, and how vital it is to examine in detail the course of history for an understanding of the transformations of society. It is necessary when analysing the "great" change of system not only to dissect it, but to know how the great change, the shift from socialism to capitalism, occurred, and what kind of formation it brought into being. Understanding that shift would have been sufficient motivation to write this second study on the system paradigm.

\section{Democracy, autocracy and dictatorship}

Political science has given rise to a great many typologies of politico-governmental forms. In this discipline too there appears the phenomenon mentioned earlier whereby authors cling tightly to their own conceptual systems or to those of some school of scholars to which they subscribe. The subject being politics, concept creation and interpretation are permeated by the differences of political opinion. In this respect this study is not meant to impose its system of concepts on anyone. I would like above all to clarify my own words. Having done so, I cannot go on here and there without arguing in their favor, pointing out the advantages of the phraseology I chose. ${ }^{22}$

22 As I stated earlier, I am not expecting others to adopt my conceptual apparatus. But at this point Don Quixote begins to tilt at the windmill of conceptual clarification, in the vain hope that others will be convinced of the advantages of the concepts and expressions I recommend. 
The typology of varieties that I employ distinguishes three types: democracy, autocracy and dictatorship. The characteristics of these types appear in Table 2.

The structure and logic of Table 2 follow Table 1 in distinguishing two great blocs: the primary and the secondary characteristics. Repetition is tiring, but let me stress again: the ensemble of primary characteristics contains the minimum conditions for distinguishing the three forms. It does not attempt a detail-rich description. On the contrary, it shows here solely the characteristics which jointly are sufficient and necessary for one or the other form to exist.

Characteristics 1 and 2 were expressed first by Schumpeter in Capitalism, Socialism and Democracy (1942/2010), and then utilized and developed further by Dahl (1983) and Huntington (1991). ${ }^{23}$ This approach singles out the procedural side of the processes of politics and exercising power as the main characteristic of democracy. Democracy has no need for the annihilation of a tyrant, for a military coup or a bloody uprising. There exists a bloodless, peaceful, civilized procedure for ousting the government: competition among several parties, then elections according to legally endorsed procedures. The loser in a democracy concedes defeat and congratulates the winner.

The simultaneous presence of Characteristics 1 and 2 in Table 2 is necessary and sufficient to demarcate democracy and autocracy at one end of the political spectrum. Characteristics 3 and 4 are not needed for that purpose as there is no difference between the two in this respect. However, all four primary characteristics must be weighed to distinguish autocracy and dictatorship at the other end of the political spectrum. Here Characteristic 3 comes to the fore: an autocracy has a legal opposition, albeit a weak one; an autocracy allows for a multi-party system, while a dictatorship rests on a one-party system. ${ }^{24}$ Here Characteristic 4 becomes decisive: terror and bloodshed reign under dictatorship, claiming millions of lives. By comparison, power is exercised almost without bloodshed under the orderly conditions of an autocracy. ${ }^{25}$

23 Quoting these authors, I took this approach in my study of the change in politico-governmental forms that occurred in 1989-90 (Kornai 2006), at a time when few people in Hungary saw the possibility of voting out the government as an important criterion of democracy.

24 Here I ignore a few parties surviving from the former multi-party systems in socialist Poland, East Germany and China. They retained their party nature only in a formal sense, while supporting the power of the communist party and operating under its control.

25 Putin has imprisoned several political opponents, but he has not used torture to extract confessions. Arresting and sentencing to many years of imprisonment was done "legally", based on the laws and legal forms of the regime. There is a ghastly suspicion that those in power may have ordered the murders of some opposition politicians and journalists, but unfeeling though it may sound, the figures must be considered when making comparisons. The number of murders committed in secret by the Russian autocracy may have been in the tens or hundreds, 
Table 2. Characteristics of democracy, autocracy, and dictatorship

\begin{tabular}{|c|c|c|c|}
\hline No. & Democracy & Autocracy & Dictatorship \\
\hline \multicolumn{4}{|c|}{ Primary characteristics } \\
\hline 1 & $\begin{array}{l}\text { The government can be } \\
\text { removed through a peaceful } \\
\text { and civilized procedure }\end{array}$ & $\begin{array}{l}\text { The government cannot be } \\
\text { removed through a peaceful } \\
\text { and civilized procedure }\end{array}$ & $\begin{array}{l}\text { The government cannot be } \\
\text { removed through a peaceful } \\
\text { and civilized procedure }\end{array}$ \\
\hline 2 & $\begin{array}{l}\text { Institutions which jointly } \\
\text { guarantee the conditions of } \\
\text { removing the government } \\
\text { are strong }\end{array}$ & $\begin{array}{l}\text { Institutions which could } \\
\text { jointly guarantee the } \\
\text { conditions of removing the } \\
\text { government are either formal } \\
\text { or weak }\end{array}$ & $\begin{array}{l}\text { Institutions which could } \\
\text { jointly guarantee the } \\
\text { conditions of removing the } \\
\text { government do not exist }\end{array}$ \\
\hline 3 & $\begin{array}{l}\text { Legal parliamentary } \\
\text { opposition exists; multiple } \\
\text { parties run for elections }\end{array}$ & $\begin{array}{l}\text { Legal parliamentary } \\
\text { opposition exists; multiple } \\
\text { parties run for elections }\end{array}$ & $\begin{array}{l}\text { No legal parliamentary } \\
\text { opposition; only one party } \\
\text { runs for elections }\end{array}$ \\
\hline 4 & $\begin{array}{l}\text { No terror (large-scale } \\
\text { detention in forced-labor } \\
\text { camps and executions) }\end{array}$ & $\begin{array}{l}\text { No terror (large-scale } \\
\text { detention in forced-labor } \\
\text { camps and executions), but } \\
\text { various means of coercion } \\
\text { are occasionally used } \\
\text { against political adversaries } \\
\text { (imprisonment with false } \\
\text { allegation, or even politically } \\
\text { motivated murder) }\end{array}$ & $\begin{array}{l}\text { Terror (large-scale detention } \\
\text { in forced-labor camps and } \\
\text { executions) }\end{array}$ \\
\hline \multicolumn{4}{|c|}{ Secondary characteristics } \\
\hline 5 & $\begin{array}{l}\text { No repressive means are } \\
\text { used against parliamentary } \\
\text { opposition }\end{array}$ & $\begin{array}{l}\text { Repressive means are } \\
\text { used against parliamentary } \\
\text { opposition }\end{array}$ & No parliamentary opposition \\
\hline 6 & $\begin{array}{l}\text { Institutions of "checks and } \\
\text { balances" are active and } \\
\text { independent }\end{array}$ & $\begin{array}{l}\text { Institutions functioning as } \\
\text { "checks and balances" are } \\
\text { weak and non-independent }\end{array}$ & $\begin{array}{l}\text { No institutions have been } \\
\text { created to act as "checks and } \\
\text { balances" }\end{array}$ \\
\hline 7 & $\begin{array}{l}\text { Relatively few officials } \\
\text { are appointed by the ruling } \\
\text { political group }\end{array}$ & $\begin{array}{l}\text { The ruling political group } \\
\text { appoints its own cadres to } \\
\text { virtually all important offices }\end{array}$ & $\begin{array}{l}\text { The ruling political group } \\
\text { appoints its own cadres to all } \\
\text { important offices }\end{array}$ \\
\hline 8 & $\begin{array}{l}\text { No legal constraints against } \\
\text { civil protest; strong civil } \\
\text { society }\end{array}$ & $\begin{array}{l}\text { No legal constraints against } \\
\text { civil protest; weak civil } \\
\text { society }\end{array}$ & $\begin{array}{l}\text { Civil protest against the } \\
\text { government is prohibited } \\
\text { by law }\end{array}$ \\
\hline 9 & $\begin{array}{l}\text { Interested persons and their } \\
\text { organizations take part in } \\
\text { many forms and to relevant } \\
\text { degrees in preparations for } \\
\text { decision-making (significant } \\
\text { levels of participation) }\end{array}$ & $\begin{array}{l}\text { There are legal frameworks } \\
\text { for participation but they are } \\
\text { practically not applied }\end{array}$ & $\begin{array}{l}\text { Participation is not even } \\
\text { formally prescribed }\end{array}$ \\
\hline 10 & $\begin{array}{l}\text { Freedom of the press is } \\
\text { guaranteed by law, and is } \\
\text { actually enforced }\end{array}$ & $\begin{array}{l}\text { Freedom of the press is } \\
\text { constrained by legal and } \\
\text { economic means }\end{array}$ & No freedom of the press \\
\hline
\end{tabular}

but the number who lost their lives in Stalin's terror was measured in millions, and those condemned to merciless forced labor in tens of millions. 
Absent from the primary characteristics is the question of how far a form expresses the wishes of the populace. This is excluded from the criteria on two grounds. One is the strong difference between the positive and the normative approaches. The enquiry here is not into what the desirable characteristics of a democracy might be. Nor is it claimed that regimes lacking such characteristics do not merit the label democracy. It is simply what characteristics distinguish the existing alternative politico-governmental forms. To remain within the positive realm of analysis, are the democracies the ones that invariably express the will of the people? Sadly, it is not rare for an autocratic tyrant or a dictator to enjoy sincere support from a large majority. Think of the masses of Germans, disillusioned by Weimar republic and sincerely supporting Hitler.

Two criteria applied when compiling the list of four primary characteristics and six secondary ones (as in Table 1). Each characteristic should appear in each case belonging to the type. In other words, it should be a characteristic common to all specific historical instances of some politico-governmental form. The other criterion is that a characteristic should distinguish one alternative type strongly from at least another. It may be that there are one or two more characteristics which satisfy both criteria. It may be that some characteristic should be described differently. I am open to all proposals that point in this direction. What I cannot abandon is the well articulated connection between the primary and secondary concept pairs. Within this interaction the effect of the primary characteristics is stronger than the force in the opposite direction - the primary characteristics are the ones that set the course of each country in a decisive way.

Autocracy, in this paradigm, is no blurred "middle way" between democracy and dictatorship, but a sharply identifiable type in the sense Max Weber termed an "ideal type". ${ }^{26}$ It is a theoretical construct that in my approach is distinct from two other types: democracy and dictatorship.

When I began to apply this typology in earlier writings, several people questioned why I was isolating exactly three types. I replied that the number three has no special attraction for me. I gladly accept other typologies involving two or four types. I am concerned solely with discerning markedly different formations.

I appreciate that many social scientists can work more easily with a concept "system" that sees current politico-governmental forms as a "mixture" - each regime displaying elements of democracy and dictatorship in different proportions. I do not want to dissuade them. I see this is more convenient for their ideas, but mine call for the use of strongly outlined types.

26 See the earlier footnote 9. 
This study deals only with politico-governmental forms prevalent in the postsocialist region, but if it extended to the whole world, it would be clear that autocracy as a type can be used profitably to analyze other regions as well.

There are vital aspects, with huge effects on the destinies of nations and individuals, which I have not accounted for in the politico-governmental forms of the triple typology. Here is one example: the concept of nationalism and policy governed thereby. Democracy gives no protection here either: think of the horrific First World War. Before it broke out, most politicians on both sides had fuelled the insurgent tensions, including the leading statesmen of French and British democracies, and then the outbreak sent a wave of nationalistic fervor over most people in both democracies. Nor were socialist countries immunized from nationalistic politics by the internationalist idea that workers of all lands should unite. Note, for example, the inter-socialist Sino-Vietnamese war of 1979. I believe in democracy but do not find it ideal. To quote Churchill's classic remark, "It has been said that democracy is the worst form of government except for all those other forms that have been tried from time to time." ${ }^{27}$ I see it as an especially important virtue that while it lasts, the government can be removed in a civilized way.

\section{The hardness and softness of autocracy and dictatorship}

The common characteristic of autocracy and dictatorship is control from above. The hierarchical pyramid has one person at its peak - a leader, autocrat or dictator whom no one orders around. Moving down from the peak, those at each level behave in two ways: obedient upwards and domineering downwards. Only at the bottom do people obey orders, but have no one to domineer.

There is a strong centralizing tendency that applies in both autocracy and dictatorship. Both systems are liable to subject to the central will as many activities and spheres as possible.

There are many means of asserting the central will: reward and punishment, primarily the actual award of recompense and the actual imposition of penalties, but promises and threats have their place too. People's actions are strongly influenced by the hope that unconditional loyalty will win favor and the fear that disloyalty will lead to reprisals.

Softness or hardness of political power refer overall to the nature of the means of coercion applied from above. Let us look at Characteristic 4 in Table 2. One of the factors distinguishing autocracy and dictatorship is that the former does not use bloodthirsty terror or other brutal means of oppression. My generation 
experienced both in the Stalinist period, when citizens feared any noise in the night: was there a black car coming to take them for torture or forced labor or to the scaffold? Here is a simple litmus test: if our lives are dominated by such fears, we are living in a dictatorship, but if they do not face fears of that kind from the regime, the politico-governmental form is "merely" autocracy.

It is also worth looking at degrees of softness and hardness at various phases of a certain politico-governmental form. The succession in history may be of several kinds. Communist dictatorship under Stalin was especially hard, but the period of Brezhnev and Andropov was more of a soft dictatorship: all the characteristics of dictatorship were present, but with less use of bloodshed or brutality in repression.

Many people in Hungary feel that life was easier in the final phase of the Kádár regime than it is now, under the third Fidesz government, which started in 2014. Certainly, for people avoiding politics, soft, decaying dictatorship is pleasanter and easier to bear than hard autocracy. It is more important, however, for the comparative theory of systems to point out the boundary between autocracy and dictatorship.

Autocracies are inclined to turn into dictatorships. If my study were not limited to snapshots, if it could depict the dynamics of history as a motion picture, it could show that autocracy can turn into dictatorship rapidly or slowly. However, the purpose of this study is not to write history, but to create types through a Weberian approach. Within these bounds it is worth making a pronounced distinction between autocracy and dictatorship.

\section{The relation between the two typologies}

This study has applied two kinds of typology. The relation between them appears in Table $3 .^{28}$

Table 3 illustrates two vital statements. Democracy does not make society immune from autocracy or even dictatorship, into which it may be turned by a combination of unfortunate circumstances, as several historical examples show. To mention only the most tragic, Weimar democracy proved defenceless against the forces of Nazi dictatorship. There are more recent examples too. Russia's shortlived democracy gave way after a few years to the autocracy of Putin.

28 The relation between the market and democracy is analyzed in Gedeon (2014). His conceptual apparatus differs from mine in several respects and there is no space here for comparing the two, but his conclusions and those of this study overlap in many ways. 
Table 3. Relation between the two kinds of typology

\begin{tabular}{lcc}
\hline Forms of government & \multicolumn{2}{c}{ Great systems } \\
\cline { 2 - 3 } & Capitalist & Socialist \\
\hline Democracy & feasible & unfeasible \\
Autocracy & feasible & feasible \\
Dictatorship & feasible & feasible \\
\hline
\end{tabular}

As said earlier, capitalism can operate without democracy, but the statement cannot be reversed. Democracy cannot operate without capitalism - "democratic socialism" is impossible..$^{29}$

Of course this pronouncement depends on the interpretation put on words: the "impossibility" applies if the expressions capitalism and socialism are interpreted as described in Table 1, and that of democracy as in Table 2.

It is not right to say that establishing the capitalist system suffices or in time produces democracy of itself. Capitalism is a necessary but not sufficient condition for democracy. Of course, the statement about the impossibility of democratic socialism depends on what is meant by "in time". Does it mean years, decades, even centuries? China in my view can be seen now as having a capitalist system, while its politico-governmental form remains a dictatorship. It has a one-party system with no legal opposition. The transition from socialism to capitalism began decades ago, but there is no sign that the country is any nearer to democracy.

The theory of a totalitarian system is associated with the work and name of Hannah Arendt (Arendt 1951/2004). Her underlying idea can only be partly fitted into my system of concepts. The last line of Table 3 can be attuned to her use of words. Hitler's Germany and Stalin's Russia are dictatorships of the cruellest, hardest kind. To that extent it is right to use the same term for them. Both were totalitarian in that the holders of power did not shrink from any means of exerting it. Both were also totalitarian in seeking to invade all dimensions of life, including the private sphere, people's most personal affairs: child-bearing, family life, personal sexual preferences, and matters of religious faith. Yet there were essential differences between them. In this analytical context I do not see as the most important differences the question of which of the two ideologies was ethically more acceptable or from the outset more disgraceful. Nor do I measure the difference in the number of millions of victims they had. The essential difference is that

29 This idea appeared in writings about socialism several decades ago. I was influenced especially by Lindblom (1977). His use of concepts differs from the one in this study, but the ultimate conclusion is the same: the democratic form of political power cannot operate under a socialist system. 
one operated under a capitalist system and the other under a socialist one. This is important not only for comparative systems theory, but for the huge difference it made in people's lives.

\section{Classification of post-socialist countries by the typology of politico-governmental forms}

Let us now apply the conceptual apparatus outlined above to the countries which counted as socialist in 1987, i.e., to the post-socialist region. Figure 3 presents another world map.

Democracies appear in light grey, autocracies in dark grey, dictatorships in black, while countries of uncertain classification have a diagonally striped pattern. ${ }^{30}$

Before commenting on the content of the map, let me mention the sources from which the two world maps (Figures 2 and 3) were drawn.

Use was made of the classifications in several well-known international reports (Bertelsmann 2016a, 2016b, 2016c; EBRD 2015a, 2015b, 2015c; Freedom House 2016a, 2016b; World Economic Forum 2016a, 2016b, 2016c). ${ }^{31}$ We placed far-reaching, but not uncritical reliance on these classifications, so that ours differ from those in one international report or another. The other source is the vast literature analyzing single countries or groups of countries. It was only possible to consult a fraction of these. ${ }^{32}$

This world map, like Figure 2, gives a static snapshot of the present, not a dynamic, film-like account showing when or how some country moved from one politico-governmental form to another. The transition in some was quite rapid and in others slow and gradual. Nor was the direction immutable; sometimes it doubled back. It would clearly be instructive to show the pace of change, but that would far exceed the scope of this study, calling for a sizeable handbook, or lengthier still, a book on each country or smaller or larger groups of countries.

30 Background Material 3 on my website shows in table form the classifications applied on the two world maps, Figure 2 and 3 in the main text, furthermore, Background Material 2 on my website. It could be said that the two maps convey in color what the table conveys in words.

31 The classifications of post-socialist countries in the reports appear as Background Material 4 on my website. I am grateful to Ádám Kerényi for his hard, circumspect work in processing these inclusive materials and his useful proposals for incorporating the information gathered from such rich data banks into the line of thought in my study.

32 Selected reference lists of the huge literature for individual countries or country groups and conclusions drawn from the study of a part of this literature are on record in the author's archives. 
I regret not having the strength for that, but hope others will undertake such huge tasks.

I would like to say a separate word on some countries. Russia, as mentioned, developed procedurally in the few years after the collapse of the Soviet Union a real multi-party system and operated as a liberal parliamentary democracy. But at one point it turned back and became an autocracy that does not shrink from tough repression (Sz. Bíró 2012). Of the Soviet successor countries, the three Baltic states, Georgia, Moldova and Ukraine can be classified as democracies. The other Soviet successor states can be seen as autocracies, with one exception: Turkmenistan counts as a dictatorship.

There is broad and thorough debate taking place on China's politico-governmental form and economy, with contributions from the West and from outside the People's Republic (Mainland China), including some from Taiwan and from Hong Kong, which is not fully incorporated into the People's Republic. Sporadically and within the limits of censorship and self-censorship come voices of those still living within the People's Republic. Let me pick a few from the varied literature: Pei (2006), Tsai (2007), Chen - Dickson (2008), Huang (2008), Schambaugh (2008), Xu (2011), McGregor (2012), King et al. (2013), Lardy (2014), Redding - Witt (2014), Székely-Doby (2014), Naughton - Tsai (2015), Csanádi (2016) and Schell (2016).

According to some, China has for a long time possessed the main characteristics of the capitalist system, although the size of the state-owned sector remains very great. In politico-governmental form it is clearly a dictatorship in all respects. For a while the dictatorship softened somewhat, but in recent years it has hardened again. The leading political force still styles itself the communist party, but it abandoned long ago the Leninist program of forcing the dominance of state ownership and bureaucratic coordination on society. Another view is that China long ago began a transition from socialism to capitalism and from dictatorship to democracy, but did so very slowly and cautiously. It will take a long time, but there will be a capitalist system in the end. This interpretation does not exclude the possibility of a slow transition towards less repressive politico-governmental forms. Indeed, the most optimistic expect the transition to end in democracy. Finally, a third view taken is that China is a unique formation, semi-socialist and semi-capitalist. All this is led by a new kind of politico-governmental form, whose characteristics differ from the standard ones of autocracy or dictatorship - China as the main manifestation of the "third road". For my part I accept the first view and China has been marked on the two world maps accordingly (Kornai 2014a, 2014b). 


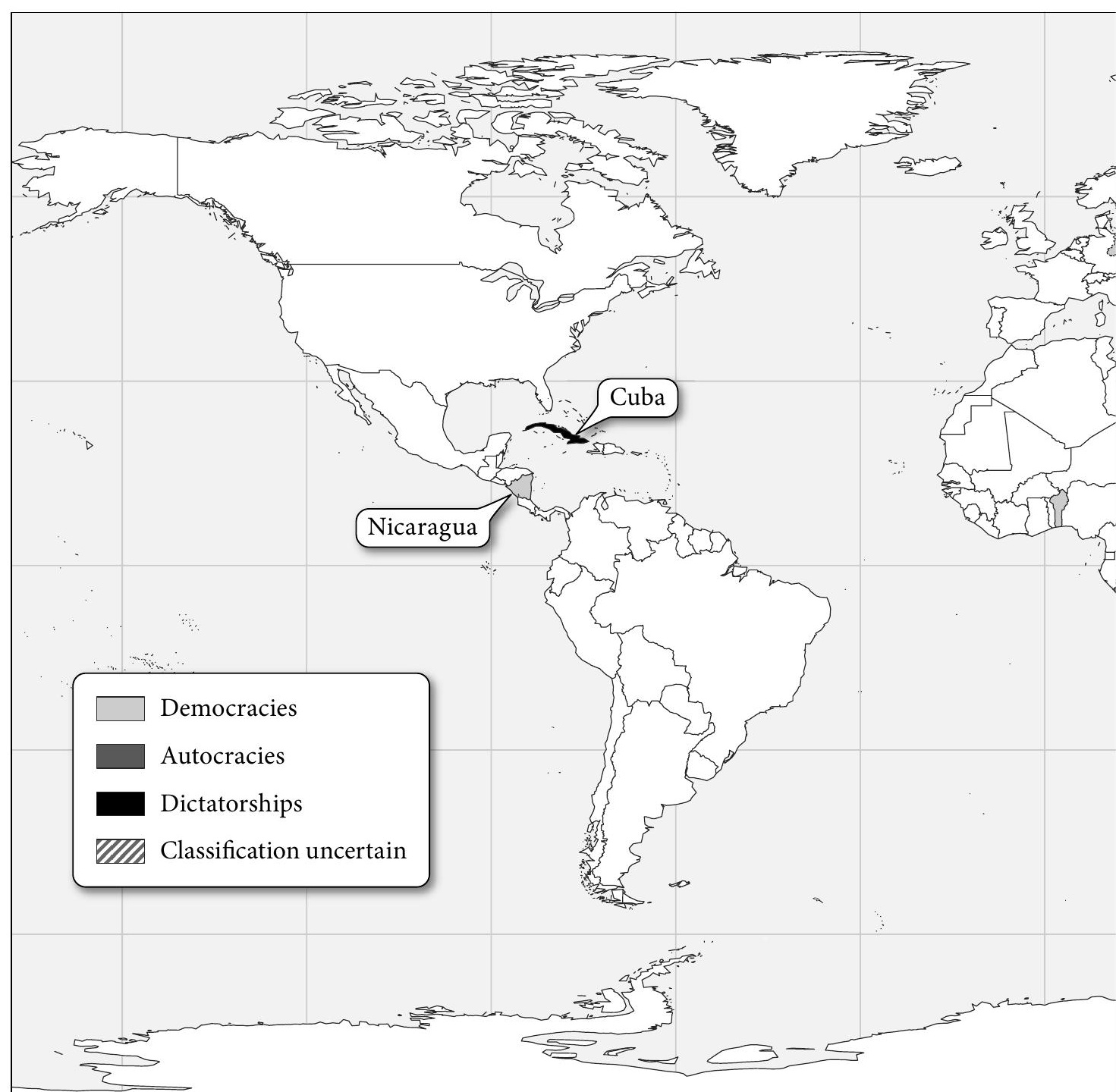

The two maps reflect the same view of Vietnam and Laos. However, the scarce amount of information available for Cambodia suggests that having suffered an especially ruthless form of dictatorship, it has since become an autocracy. ${ }^{33}$

33 As in China, classifying the system in the three Indo-Chinese countries is in dispute. See, for example, London (2014) and Benedict - Kerkvliet (2015). 


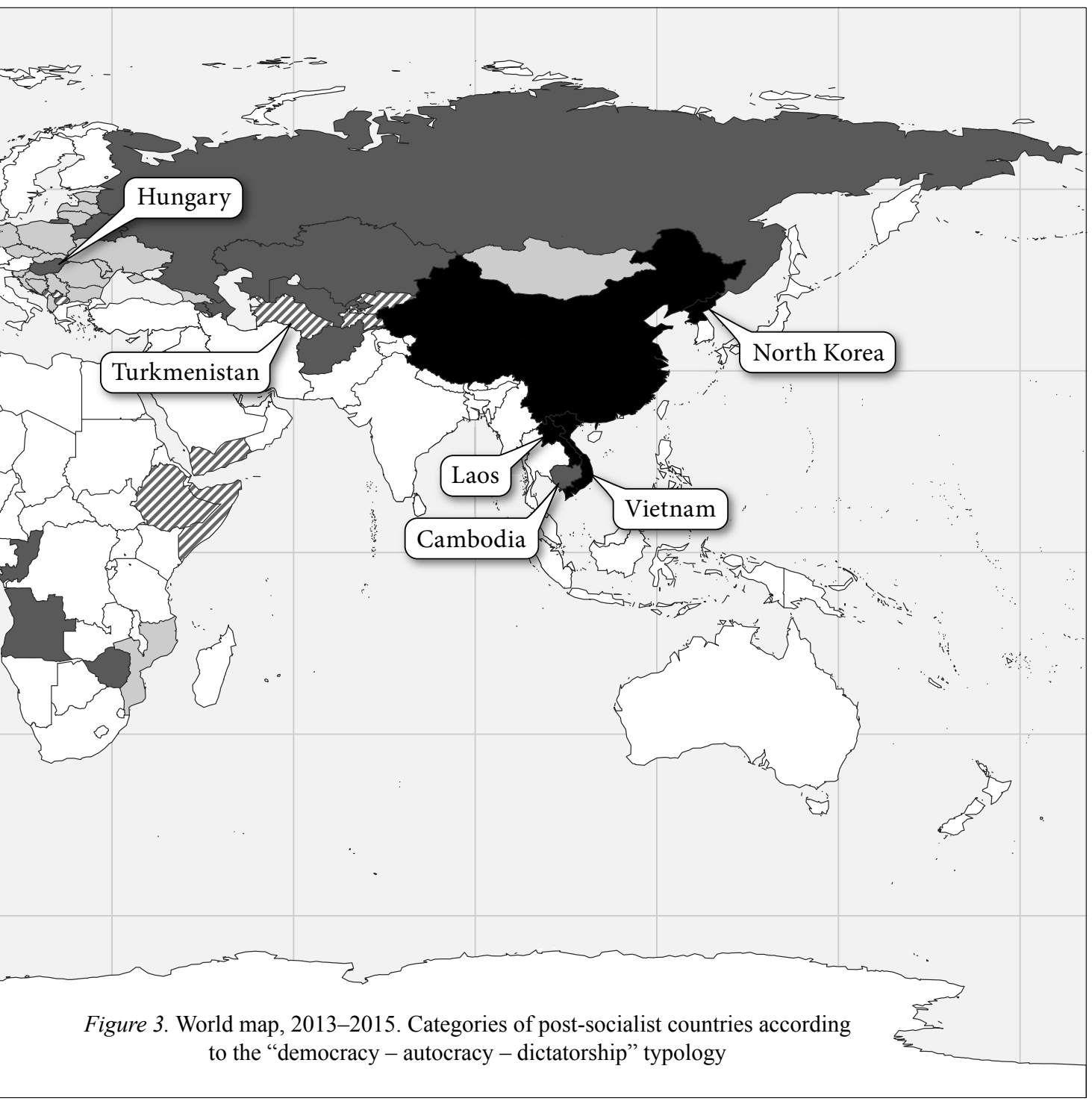

In Figure 2, showing the "socialism versus capitalism" typology, Cuba was classified as a country in transition from socialism to capitalism, although it was still taking the first steps. The one-party system remains and no opposition can operate legally, so that it has been placed among the dictatorships in Figure 3. The dictatorship is still there, though softened and somewhat less repressive, but the possibility cannot be excluded that its politico-governmental form will move towards autocracy or even democracy. Yet there is a big chance that while private 
ownership and market coordination spread, the politico-governmental form will remain a dictatorship.

Some countries of the post-socialist region has been marked with diagonally striped pattern, to signify the author's uncertainty about which type to place it in. This may have several reasons:

(a) The country has undergone or is undergoing armed conflict. The politicogovernmental form may be varying between democracy, autocracy, and even dictatorship. These cases can be found on my website in Background material $5 .{ }^{34}$

(b) Islam is the most prevalent religion in many of the countries. In some it leaves no mark on the operation of the economy or politico-governmental form, but in others a specific theocratic form of politics and government emerges. This could be seen as a sub-type of autocracy. Information again appears in Background Material 5. I do not feel conversant enough with the Islamic world, so these countries remain problematic and I have marked them with the diagonally striped pattern.

(c) Finally, there are some post-socialist countries that do not belong to either (a) or (b) (cannot be characterized with armed conflicts or the increased political power of Islam), but insufficient information precludes me from placing them in my own typology, and I have marked them with the diagonally striped pattern for that reason.

\section{In defence of the term autocracy}

Between the extreme types of democracy and dictatorship there is a middle type which cannot be termed as either. There is a large measure of consensus about this among political scientists and exponents of comparative system theory. However, there is no such consensus on the criteria for separating democracy and the intermediate type. Similarly, it is hard to gauge whether a country is a case of the intermediate type or a dictatorship. All I can do in this study is what I did in my earlier works: present readers with my own criteria for distinguishing the three types. These criteria are summed up in Table 2. Whether readers agree or not, let it at least be clear how the author has defined the three forms.

The choice of types ties in closely with their names. Many of the terms used in the political sphere have a political ring to them, which means we have left the realm of positive, value-free description for that of normative analysis that engenders value judgements. I do not want to shut my eyes to this phenomenon.

34 I am grateful to Andrea Reményi for researching Background Material 5 and compiling Table 2. 
My use of autocracy for the middle type arises partly from my system of values and political convictions. I am a democrat devoid of illusions. Despite its shortcomings and dangers I rate this political form best. It would be a big mistake for believers in democracy to let the word be used for forms of government whose fundamental characteristics are not democratic, and I am wholly against doing so. The problem cannot be avoided by qualifying what to me stands for something so valuable. I dismiss for normative reasons such combinations as "illiberal democracy" or "leader democracy" and judge the use of them as harmful. ${ }^{35}$ I distinguish the characteristics of democracy and autocracy as types in Table 2 in such a way as to exclude any kind of "illiberal" or "leader democracy" from the former category.

Many people no longer recall the official nomenclature of communist ideology. That too used a qualifier. The dictatorship under the socialist system was known as "people's democracy". This was advanced as true democracy, as opposed to "bourgeois democracy", which was dismissed as mere verbal democracy, for it served the bourgeoisie, not the people. My conceptual apparatus defines the characteristics of democracy in a way that requires no grammatical attributes.

\section{The declining "third wave" of democratization}

I was strongly influenced by the work of Samuel P. Huntington, especially The Third Wave (Huntington 1991). Were he to read this study he would probably fault me for putting mere static snapshots on the two world maps. History in his view could only be conveyed dynamically. If only I had the strength to create a book to include, along with other things, a dynamic description of the transformation processes in each post-socialist country. This study cannot attempt that. As shown earlier, I am imparting static snapshots, which I see as important, useful and workable despite their limitations. They provide handgrips for the analysis by distinguishing each type sharply: the capitalist system from the socialist, the democratic politico-governmental form from autocracy, and autocracy from dictatorship. In my view, it is the absence of such sharp distinctions that leads to

35 The expression "illiberal democracy" was coined by Zakaria (1997), but when Viktor Orbán used it to characterize his own Hungarian politico-governmental form, there was widespread protest and Zakaria himself dissociated himself from such usage in an article (Zakaria 2014). The term "leader democracy" occurs even in the title of a study by András Körösényi (Körösényi 2003). The antecedants in theoretical history go back to Max Weber and Karl Schmitt (Weber 1922/2007; Schmitt 1927-1932/1996). For some further notable contributions to the debate on the boundaries and variants of democracy, see Krastev - Holmes (2012), Körösényi - Patkós (2015), and Szelényi - Csillag (2015). 
Table 4. Distribution of alternative forms of politics and government in the post-socialist region

\begin{tabular}{lcc}
\hline & \multicolumn{2}{c}{ Percentage of } \\
\cline { 2 - 3 } & Region's population & Region's area \\
\hline Democracy & 10.3 & 11.3 \\
Autocracy & 14.8 & 56.7 \\
Dictatorship & 68.4 & 26.1 \\
\hline
\end{tabular}

Note: Data, rounded off to one decimal place, were drawn from Background Material 4, available on my website, and were calculated on the basis of Background Materials 1 and 3, published on the same site. The totals of the two columns are less than 100 by 6.5 and 5.9 percent, respectively. This difference comes from the fact that some countries listed in Background Material 3 were not assigned to any of the three groups - their classification was considered uncertain.

strongly debatable or even erroneous placement of the post-socialist countries in Huntington's figure (Huntington 1991, p. 11, Figure 1.1).

According to the typology of this study, there was communist dictatorship in East Central Europe and the Baltic before the events in 1989-92, although the repression had eased somewhat in some countries. The winds were blowing towards democracy, but according to my strict criteria, the minimum conditions for democracy were not met. Huntington, however, lists Hungary, Poland, East Germany and the three Baltic states as countries where the first wave of democratization took place, ${ }^{36}$ while he places Bulgaria and Mongolia among those involved in the third wave of democratization.

An often quoted metaphor is the glass half-full or half-empty. Huntington rejoiced (as did millions, I among them) that wave after wave of countries joined those with democracy. We are glad that there is a little more water in the glass after some decades. But looking at Figure 3, the world map of the distribution of politico-governmental forms, it is a bitter sight to see the countries with glasses half or three quarters empty. The Soviet Union collapsed, Mao Zedong's reign of terror ended, yet only a tenth of the inhabitants and area of the post-socialist region live in countries that can be classified as democracies. The proportions appear in a little more detail in Table $4 .^{37}$

There are no serious signs that democratization is continuing - Huntington's third wave has ceased. In fact, Hungary has undergone what Huntington calls a "reverse wave": a democracy that worked better or worse for a decade or two has

36 I suspect that the six countries were entered on Huntington's diagram in the wrong place. It emerges from the context that, according to his own periodization, these countries set out on the path of democratization not in the first wave, but in the second, which reached its zenith in 1962.

37 For more detailed summary figures, see Background Material 4 on my website. 
relapsed into autocracy. ${ }^{38}$ There have been plenty of signs of this. Since the general elections in 2016, Poland has started along the Hungarian road by destroying important institutions serving as checks and balances and moving away from democracy and the rule of law. And who knows how many other countries will be subjected to the reverse wave. ${ }^{39}$

\section{Empirical support for the maps}

The main purpose of this study is to review my own conceptual apparatus, and in that connection, outline two typologies, and present the criteria that distinguish various types. There are no "proving" concepts or typologies. They are no statements whose truth can be confirmed or refused empirically. The conceptual apparatus and typology of a work belong among the tools of the researcher. They are expected to be workable and assist in understanding the truth. I consider that the apparatus outlined here fulfils that purpose, and I hope to convince as many readers as possible of the same. On the other hand, the qualifications made on the basis of my own system of concepts and typology (the two maps, Figures 2 and 3 in this text, Background Material 2 and the table shown in Background Material 3 on my website) are propositions, susceptible to refusal. Any of the presentations of countries on the map may reflect the truth rightly or wrongly (given the criteria for placing them). The assertions made by the grey and black tones may be true or false, confirmable or dismissible and replaceable by a different assertion.

Several international organizations are engaged in preparing comparative reports to show how countries fare in building up the institutions for their capitalist market economies, in ensuring civil rights, or to what extent their forms of government can be considered as democracies, dictatorships, or other formations. Each report follows a distinct methodology with differing typologies and classifications. Unfortunately, I am not aware of any study designed to compare such

38 The image of a reverse wave is vivid, but not accurate enough. When the wave moving towards democracy and a capitalist market economy reverses, it does not arrive where it began. There is no sign of the communist system being restored. It was a common remark among the transition specialists of the 1990s that you can scramble eggs, but not unscramble them again.

39 It is thought-provoking to read an article by Katalin Balog, a US-based philosophy professor born in Hungary, pointing to similarities between the changes in Hungary and the "Trump phenomenon" in the United States (Balog 2016). What is shared most closely is the change in political discourse: it has become acceptable in speech and writing, social discussion, political speeches and press articles, to proclaim racism, xenophobia, and national supremacy. These prepare the ground for turning away from democracy. Balog points to a study by Taub (2016), which examines the strengthening of American authoritarianism. 
reports with each other or look critically at their methodologies. My assistants and I have mainly used the materials of two organizations: Bertelsmann (2016a, 2016b, 2016c) and Freedom House (2016a, 2016b). While I rate highly the huge, conscientious research effort in them and appreciate that the reports are available free of charge to politicians, media people and academics, I do not agree with their methodologies, conceptual frameworks and criteria in many respects..$^{40}$ Let me mention a few of these. ${ }^{41}$

My study categorizes in a different way to produce a typology of politico-governmental forms. As mentioned, a central place is held by Schumpeter's procedural approach: reflecting on whether the government can be voted out of office in well-defined, civilized, multi-party elections. This embraces the stability of the system of checks and balances and effective intervention, the degree of independence of civil society and lower-level organizations from central government, the relative strength of centralizing and decentralizing tendencies, and so on.

What I miss most from the reports mentioned is one of the main ideas in this study: they do not sufficiently perceive whether the interaction between constituent anti-market or anti-democratic phenomena produces a coherent system. To use an old-fashioned Hegelian expression, the reports in the study of several countries did not perceive the critical point where many small quantitative changes turn into a qualitative change. It is as if a student were having a given performance rated by several different teachers. In many cases I rate more strictly than a Bertelsmann or Freedom House report. ${ }^{42}$

40 For an overview of reports compiled by international organizations see Backgound Material 6 on my website. Both Bertelsmann and Freedom House reports use quantitative indicators and qualitative denotations concurrently to convey the state of the country examined. Freedom House's qualitative classifications are tied wholly to quantitative indices. Certain ranges of democracy scores (DS) are translated into a qualitative description (e.g., a DS score between 6.00 and 7.00 counts as a "consolidated authoritarian regime"). So the entirety of Freedom House's verbal expressions does not amount to a typology, for as I have mentioned, a typology emphasizes strong, shared qualitative characteristics. Instead, a Freedom House report undertakes a complete classification of each country, giving each class a name. This is justified methodologically, but differs from what this study sets out to do. That is why I have dealt with this in a footnote, not the text, where I will put down my reservations and critical observations.

41 I fully understand the desire of the international comparative reports to add quantitative indicators to their qualitative types, but I cannot cover the advantages and drawbacks of using them in this study, which is already too long as it is.

42 Bertelsmann reports make no use of the term dictatorship in their qualitative ratings, preferring to talk of "hard-line autocracy". Of course they have a right to name things as they will, but it is unfortunate to omit from their vocabulary such a graphic, widespread expression as dictatorship. No doubt my regret at this omission is due to my sterner value judgements. 
Let me recall here Table 2, which compares the characteristics of the three politico-governmental forms, notably Characteristic 7: Which positions does the ruling political group occupy for its own people? To what extent does a degree of civil-service autonomy cease? What proportion do "political appointees" represent of all the functionaries? On paper an institution is seemingly independent, but in fact it is wholly controlled by people subordinate to the central will. This phenomenon is ill-considered or underestimated by the organizations making international comparisons, vital though it is to the transformation of democracy into autocracy, or even dictatorship. They are impressed by the rules expressed in formal, public words, while unaware of the background selection processes whereby the top leader and his subservient underlings place their own people in all important positions.

Here I have merely compared the rigor or indulgence in handing out grades, without considering the empirical grounding of the judgements. Both Bertelsmann and Freedom House reports make strong, careful assessments with armies of specialists, huge piles of documents and vast data banks behind them. There are no such armies behind my two world maps, just research by a few assistants and my own analyses. It is with due modesty and caution that I put forward these compilations, knowing that the rating of each country is debatable. To return to the earlier metaphor: I feel I am not authorized to dispense grades against which there is no appeal.

\section{HUNGARY'S PLACE ACCORDING TO THE TWO TYPOLOGIES}

\section{Applying the general methodological frame to the experience gained in Hungary}

This part of the study does not aim to supplement the picture drawn about the nature and power structure of the political force ruling Hungary since 2010. There are many shelves full of such studies already. ${ }^{43}$ Each day brings new twists, criti-

43 Prior to the victory of this political force at the 2010 general elections, József Debreczeni managed to predict the likely developments in several fields (Debreczeni 2009). First after the assumption of power to show the radical changes and processes occurring was a study by Gábor Halmai (Halmai 2010), followed by my own study, "Taking Stock” (Kornai 2011), which pointed out a radical transformation, i.e., that the government had already dismantled some essential institutions of democracy and begun to build up its autocratic rule. Apart from a huge number of press articles examining the matter there were several academic studies, of which I should highlight here Ágh (2016), Bauer (2016), Bozóki (2016), Kornai (2012, 2015), Körösényi (2015), Magyar (2016) and Magyar - Vásárhelyi (2013, 2014,2015). 
cal reports of which can be found in the press. Nor will I attempt here to make all my earlier writings "up-to-date" with the present study.

Hungary is the post-socialist country I know best. I would like to apply the analytic apparatus offered in this study - primarily the conceptual framework and the two typologies - to the specific Hungarian experience. Can Hungary be fitted into the two typologies, or is it a single, unique case? This application tests the viability of the analytical apparatus, the conceptual framework, and the typologies. It also presents an opportunity to go beyond the specific Hungarian case and add some further thoughts of more general validity.

\section{Hungary's capitalism}

Let us turn back to Table 1. All three primary and all six secondary characteristics of capitalism apply in Hungary. It is not on any "third road". It cannot be classed as a non-capitalist, non-socialist system.

Capitalism is a very strong system, capable of significant achievements even under inimical conditions. Its strength has been apparent in Hungary, above all in acceleration of technical progress. Achievements of the high-technology period spread at a rapid pace, and the country itself contributed more than one revolutionary innovation. Despite many mistakes and omissions in economic policy, the economy has climbed out of its trough. GDP is rising, although the growth rate is modest: it is not as fast as the acceleration usually manifesting during rapid growth after a crisis. This is true capitalism, although the beneficial aspects of it have been weaker and the repugnant ones stronger than those experienced in many more favorable variants.

The ruling politico-governmental system exerts a strong influence on the Hungarian economy, but I do not find it apposite to call it "state capitalism". ${ }^{44}$ That term is surrounded by utter confusion. Many use it to assert that the state has adopted functions of capitalist private ownership, or that the state itself has turned capitalist. That is certainly not the case. However strong the desire of those in power may be to increase their wealth, it is wrong to see this as a single motivat-

44 The term "state capitalism" has been used by politicians and political analysts of various persuasions (from shades of the socialist and communist movements through liberals to fascists). Some apply it to a formation congenial to them, others to one they oppose. A serviceable account of its history appears in Wikipedia [https://en.wikipedia.org/wiki/State_capitalism]. One interesting branch of Hungarian discourse on the subject was the 2005 debate between János Kis and Gáspár Miklós Tamás (two philosophers) on socialism, capitalism and state capitalism (Tamás 2005; the 2005 article by Kis was published again in the author's volume of collected writings: Kis 2014, pp. 429-439). 
ing force. The machinery of the state is not being operated according to the rules of the capitalist market economy.

All kinds of capitalism display entwining of the political sphere (the state apparatus run by ruling parties, legislators and the government leadership) with the business sphere. This entwining is unusually strong in Hungary, and occurs along many strands and by many means. All kinds of capitalism bring corruption. This is unusually common in Hungary, involves huge sums of money, and appears in many different forms. This entwining and corruption appear at first glance as a proliferating jungle, but further examination of it reveals a few characteristic features:

1. The state sector is spreading again, if only to a modest extent (Mihályi 2015). The form it takes is usually not confiscation of privately owned firms, banks or other organizations, though that too occurs. The methods are more refined. The state often buys up hitherto privately owned firms, banks or other organizations at depressed prices, having first used state powers to impede their operation and turn them into lossmakers. It then places its own loyal people at the head of such a state-owned firm or financial organization. This gains it strong positions in business life.

2. Often a business unit on the verge of collapse is bought by the state at a negligible price, then boosted from public funds, rendered viable again, and reprivatized. The selling price will not be high and the gains will be made by new owners close to Fidesz, the ruling party.

3. A very high proportion of state expenditure goes on financing the current operation of the governmental machinery, and on investments financed wholly or partly out of public funds. To the latter can be added as a source the large contributions for structural transformation of the country received from the European Union (EU), whose allocation rests with the Hungarian government. All these state expenditures are spent in a biased way. Where loopholes in the law allow, the procedures for public procurement are circumvented. Where there is no way of avoiding them, they are bent to ensure that firms close to the governing party make the winning bids. This allows giant firms or empires of companies to expand at great speed, and it can be that some of the extra profits find their way back into the pockets of those who eased the path to winning the competitive bidding. Normally the police and the state prosecution show no inclination to seek evidence of such apparent corruption. ${ }^{45}$ Decision-makers are often led by politi-

45 To an extent the task of investigating corruption is taken up by non-governmental media, research groups and opposition politicians. (To pick an example, a report of the Corruption Research Center Budapest (2016a) produced comprehensive data based on a very large sample.) But revealing corruption is only a first step. Its effects are limited unless published suspicions 
cal bias and personal advantage in matters of public procurement, careers in state service, pay of leaders, bail-outs of endangered firms and other organizations, and softening of budget constraints. The beneficiaries become loyal supporters of the ruling group; a patron/client relation develops between holders of political power and those to whom they give preference. There spreads the repugnant phenomenon known in the literature as clientelism and crony capitalism.

4. To the cases just described can be added all-too-common ones where beneficiaries have family or kinship ties with decision-makers. Such immoral occurrences have long been known as nepotism.

5. The arsenal includes not only reward, but dissuasive punishment. If the head of a capitalist group aims too high or moves too close to the pyramid of power, there is retaliation: procurement bids and business takeovers will fail, administrative penalties will be imposed, and regulations will appear that restrict activity.

6. The expression state capture has joined the vocabulary of political studies and is not rare in Hungary either: legislation and other regulations are tailored to the needs of specific capitalist groups. The opposite effect is at least as common: the state captures the business realm. State leaders appoint and dismiss the oligarchs. Such intervention by politicians and bureaucrats extends from the top of the business hierarchy down to the middle management levels. They decide who gets rich quick, sometimes with lightning speed, and whose wealth diminishes.

This particular Hungarian variant of collaboration of the ruling political group and the business realm, with dominance of the former and widespread corruption, has led to the term mafia state, coined by Bálint Magyar and now widespread in political parlance. ${ }^{46}$ There is certainly a strong similarity between what happens in Hungary and in the mafias of Italy, the United States, Russia and many other places. Luckily for us, there are essential differences. The "godfather" or small group ruling a mafia punish insubordination not with dismissal or employment in a less powerful but still comfortable position, but with execution. A death threat ensures unconditional obedience. It is a stronger disciplinary method than demotion and/or deprival of fat earnings. ${ }^{47}$

are followed by police investigations, criminal charges, court procedures, and penal sentences on the guilty. That is all a state monopoly. Not even the most impartial judge can sentence those against whom police and prosecutors have not made impartial investigations and filed charges.

46 Bálint Magyar began using the expression in the early 2000s. For details on this term, see Magyar 2016, pp. 1-55 and Magyar - Vásárhelyi 2013, pp. 9-85. See furthermore Magyar Vásárhelyi 2014 and 2015.

47 Albert Hirschman pointed out in a brilliant essay that there are two organizations against which there is and can be no opposition, either by voice or by exit: Stalinist power and the mafia (Hirschman 1970). Under today's Hungarian system it is possible to protest by word of mouth or by exit, or if all else fails, by the extreme form of exit, leaving the country. 
Most of Characteristics 1 to 6, elucidated above, are not fuelled merely by motives of power or money. There can be discerned in them also a nationalist tendency. Where possible, preference goes to businesses in Hungarian, rather than foreign or multinational ownership. ${ }^{48}$ This is one normative principle when judging public procurement bids. The nationalist government may also resort to other weapons, such as manipulating the foreign exchange rate. A falling Hungarian forint will make imports more costly and thereby improve the sales chances of more expensive Hungarian producers, at the expense of consumers.

Leading government politicians are often heard to make anti-capitalist remarks. This should not mislead people. The system under which Hungarians live is a capitalist one.

\section{Hungary's autocracy}

Let us turn back to Table 2. All four primary and all six secondary characteristics of autocracy are met in Hungary. I am aware that the state of affairs in Hungary is still a matter of debate among critical domestic and foreign analysts: Can Hungary be called a democracy even though many chances have ensued that are alien to democracy? As I noted earlier, there is no consensus among specialists, politicians or politically minded citizens on how to interpret the concept of democracy, and so I am not expecting this study to convince anybody that it is wrong to qualify Hungary as such. I trust only that for those who have followed the study so far it is plain and clear that Hungary is an autocracy according to the typology presented here.

Let me stress the minimum conditions for autocracy: a government that cannot be voted out by the customary democratic processes; a system of institutions (introduction of electoral regulations advantageous to the incumbent political force, reduction of the funds required for the opposition to function effectively; drastic curtailment of the influence of the opposition press and media, etc.) that almost guarantees Fidesz electoral victory. ${ }^{49}$ The ruling party fills leading positions at all levels with its trusty people. It has installed its own "checks and balances" even for the unlikely event that the opposition wins the elections, assuring that the reli-

48 There are exceptions. A strong, prestigious multinational firm with a "strategic agreement" with the government may receive special treatment. Where two priorities clash - strengthening central power and nationalist bias in favor of Hungarian capital, the former usually proves stronger.

49 If need be Fidesz will enter into open or secret coalition with the far-right party Jobbik. The nightmare memory looms of the fall of Weimar democracy: the coalition of former Chancellor Franz von Papen and other conservative politicians with the Nazi party. 
able people appointed by the present ruling group will remain in key posts and impede the normal operation of a new government.

It came as no surprise to those who looked at likely events without wishful thinking. ${ }^{50}$ True democrats can accept it if they lose an election. Viktor Orbán could not accept his defeat in 2002 and 2006 and resolved it should never happen to him again. In his famous speech at Kötcse in 2009 he announced in advance that Hungary needed a right-wing regime that could stay in place for at least 15-20 years. ${ }^{51}$ I count myself among those who took Orbán's determination seriously. The first signs of him building an autocracy were clear a few months after he took power.

Unfortunately, the first signs of danger had little effect. Years went by before the full danger to democracy became clear to Hungarian and foreign observers. The reactions of the EU and other international bodies were slow and feeble. Democracy is a fragile and vulnerable politico-governmental system, since its very liberalism makes it grant freedom of expression and assembly also to enemies of democracy. The EU, built on democratic principles, had, and it seems, still has no effective means of halting anti-democratic actions.

Autocracy, as I said earlier, may be softer or harder. In Hungary, the signs of hardening are appearing, but I still would not class the present situation as dictatorship. It suffices to look at Table 2. Among the primary characteristics of a dictatorship is a one-party system with a total absence of legal opposition. Likewise a primary characteristic is terror: mass arrests, grim forced labor camps, mass political murders, death sentences imposed under arbitrary rules devised by the dictatorship, or exceeding even its own laws, investigators who torture their victims or shoot them dead.

Memories of dictatorship are still strong in the older generations, and they can distinguish between autocracy and dictatorship at a glance. A false distinction may arise not only from wishful thinking, but from fear (perhaps not unfounded) of a bad future that has penetrated our thinking. Autocracy, as the middle politicogovernmental form in the typology, must be distinguished from democracy on the one hand and dictatorship on the other. ${ }^{52}$

50 "Wishful thinking" describes well the particularly distorted, biased outlook on future events: individual desires and hopes are embedded in rational and objective thinking, which unavoidably blurs the boundary between a positive aspect (what is) and a normative aspect (what should be).

51 Orbán's speech was heard a few months before he took power. An edited version appeared in the weekly Nagyitás early in 2010. The references to this study include the URL for the text at the Fidesz website (Orbán 2009/2010).

52 I understand the horror at the danger of fascism, but disagree with those who term, like Ungváry (2014) in his otherwise excellent volume of analyses, the Hungarian politico-governmental formation "fascistoid". 
Nor is the leadership cult a specific characteristic among the three types in my typology. The admiration for Viktor Orbán that has arisen, in part spontaneously and in part artificially, is not an exceptional phenomenon, not one apparent only in Hungary. It appears in almost all autocracies and dictatorships, either in an extreme form almost of worship of the leader, or more soberly. More rarely, charismatic figures may appear in democracies as well: the aura around Churchill, or later De Gaulle or Roosevelt, in the critical periods of the Second World War. I avoid the widespread term "authoritarian" regime or "authoritarianism" for blurring the distinctions, because in a democracy, an autocracy or a dictatorship alike there can appear a person at the peak of power who has high prestige and authority, whether to serve good purposes successfully or evil ones cruelly, whether the admiration is voluntary or thrust upon the people, and whether the person on the peak is worthy or unworthy of respect.

\section{The foreign policy of the Hungarian government}

Mention has already been made of strong nationalist tendencies in the autocracy of Hungary, but only in domestic affairs, for the benefit of Hungarian producers and entrepreneurs, at the expense of foreign-owned or multinational companies in Hungary. To this has been attached a well-known "national" economic policy: making imports harder, for instance through monetary policy that pushes up their prices. Let us now extend the examination to foreign policy.

Memories of the catastrophes and bloodshed of the two world wars, careful study of how the conflicts arose, and the conclusions drawn prompted Western European statesmen to found the association of countries which evolved into today's European Union. Let there be no more war among the great countries of Europe, not least because such war had burgeoned into world war twice in the last century. Also behind this was a community of economic and political interests, but the prime purpose was to ensure peace in Europe: peaceful coordination of their countries' interests and a common approach in support of European ideas, rather than threats and armed conflicts. From the outset there were internal antagonisms to contend with: integration to the degree found in the United States was out of the question in a region of European countries deeply affected by centuries of national traditions. Within every member state there is rivalry between political forces ready to concede more sovereignty and those not prepared to do so and wanting to move back to the fullest degree of sovereignty.

Although these two forces exist in all EU countries, it is specific to Hungary to find such methodical efforts to weaken EU powers, ignore its regulations, exploit legal loopholes, and make anti-Brussels rhetoric integral to official government 
policy. This approach has been taken by Prime Minister Orbán in a small member state dependent on imports and foreign investment and on the EU funds available for free. He is becoming known increasingly abroad as a leading light in nationalism and rebellion against European cohesion.

Of assistance to the ruling Hungarian political force in this was the wave of refugees from war-torn countries that reached Hungary in 2015: people by the hundred thousand, mainly Muslim adults, seeking the security and higher living standards of developed European countries. Many of them lack the ability or will to assimilate. There begins to appear a case of what Huntington described in a 1992 lecture as a clash of civilizations (Huntington 1996). The wave of refugees found the leaders of the most developed countries unprepared. They responded with human empathy, as humanism dictates and all true democrats can only agree with that. But they did so without a plan for containing an unending stream, or organizing and financing the coexistence with the people streaming in. The words and acts of the European political leaders were hasty and inconsistent. The confusion, impatience or even xenophobia arising in several countries was enhanced by bloody acts of terrorism, and by the terror and threats of ISIS. Orbán from the outset refused decisively and clearly to grant any migrants refuge. He expressed crude outrage against the volunteers who displayed humanitarian sympathy towards them. His rough words stirred an outrage among people who expressed humane empathy for the suffering, but enthralled members of the Hungarian public who were already inclined to xenophobia. Hungary became the first country in Europe to erect a razor-wire fence along its southern borders. This act was initially condemned, but later imitated by foreign politicians.

I will not detail the further problems arising from the migration wave and acts of terrorism, or conflicts between national sovereignty and European cohesion. I simply want to indicate these factors and place them in the thematic field of this study. Nationalism and xenophobia are not specifically Hungarian, but the methods chosen by the ruling party and government for addressing these ambiguous problems are constituting a Hungaricum..$^{53}$ There is a danger that Hungarian policy will make waves beyond the country's borders and attract adherents. Hungary, sadly, has a tradition of policy swings. The group in power likes to call its rule democracy and claim Hungary a place in the culture of European Christianity. Meanwhile there are heard repeated speeches that belittle Western democracy and talk of the decline of the West, while lauding many Eastern versions of despotism, citing the tyrannical regimes of Russia, Kazakhstan and Azerbaijan,

53 The nationalism of the political group in power has deep roots and traditions which date back hundreds of years. On this topic see Agárdi (2015), Kende (2013), Rainer (2012, 2013), and Ungváry (2014). 
the hard-line government of Singapore, the semi-feudal Islamic autocracies of the Arab sheikdoms, and the ever-hardening dictatorship in China. Clearly there are also economic intentions behind this: the Eastern orientation is expected to yield investment, loans and big orders. But there are other motives too: affinity felt between its own autocracy and the methods of Afro-Asian despotism. This double game is also unique to Hungary: it is not a common characteristic of all autocracies.

\section{A Hungarian hybrid?}

Some decades ago I gave a lecture taking issue with those who sought an "optimal" system, a combination of the best rules of the game. Let me quote what I said: "Those aiming for this somehow imagine themselves in a big supermarket. There on the shelves can be seen the various mechanism constituents, embodiments of various beneficial system characteristics... Those designing a system have nothing to do but gather up 'optimal elements' into a shopping cart and go home to fit up an 'optimal system'. Except that this is a naive dream. History does not maintain any such supermarket from which we can choose at will... The only choice for those deciding what system to adopt is between various pre-packaged tie-ins" (Kornai 1980b, p. 290).

So when Viktor Orbán and his political partners built up their power, were they refuting, through their deeds, my assertion of 36 years before? Has it rendered the metaphor of history's supermarket offering system elements erroneous?

Many people see the actual Hungarian system of today as a particular mix of the socialist and capitalist systems, containing elements of both, as a half-socialist, half-capitalist hybrid. It is also thought widely that Hungary's politico-governmental form is a particular mix of democracy and dictatorship, it is a hybrid, obtained by the cross-fertilizing of a democracy-plant and a dictatorship-plant.

My study rejects this system-theoretical innovation. The Hungary we inhabit is no hybrid. It is a special kind of capitalism, and a specific kind of autocracy. The conceptual frame and analytical apparatus of my study lead directly to this conclusion.

I must not omit to say that the supermarket metaphor only defines the sharp contours of the social formations. Beside other experiences, the changes in Hungary also point to a need to refine my earlier theory.

There appear in the capitalism of present-day Hungary and other countries $i s-$ lands that resemble socialism. Foremost is the health-care sector, where the state dominates the supply side in many countries, while on the demand side free or almost free provision is offered. This generates a secondary socialist character- 
istic: a shortage economy. Symptoms can be seen: actual queuing in out-patient clinics or virtual queuing on arbitrarily long waiting lists. Concomitant is a grey or black economy of gratuities to medics that ease frictions in by lubricating the machinery of the official supply. Yet such socialism is literally an island in a capitalist sea.

The transition to capitalism is largely over in Hungary and the other postsocialist countries, but much of the legacy of socialism remains, above all in people's mentality. Far from disliking the paternalism of the state, many dispute their responsibility to see to themselves and expect the country's leader to guide and look after them. That is one reason why Hungary underwent such a smooth turn away from the rule of law, the enforcement of contracts, and broad local self-governance. Centralization has strengthened. However, the ruling political power has no intention of returning to the starting point, to the position before the change of system by restoring socialism. After carrying out the turn, they halted on the road which leads away from democracy, rule of law, decentralization, and respect for private ownership. The regime has every reason to maintain the autocratic capitalism in its particular Hungarian form. As mentioned before, the intention is far from ending the dominance of private ownership. What the regime really wants is reinforcing the links between the ruling political force, leading bureaucrats and the business realm, and thus strengthening the position of political power holders therein. The aim is not to abolish the market, simply to intervene in populist manner (such as arbitrarily reducing certain utility charges below the market price), and/or to interfere crudely in the fine machinery of market coordination for selfish financial gain. Since the primary characteristics of capitalism have survived, the Hungarian system of institutions is not semi-socialist and semi-capitalist. Capitalism persists, but in a specifically Hungarian form where its repugnant characteristics are particularly strong.

The present politico-governmental form in Hungary was not brought into being by a leading politician pushing a shopping cart round and filling it with elements of democracy and dictatorship, in order to aptly assemble their "optimal" combination. It was more a question of selecting various specific elements of the system sitting on the shelves like different loaves in the supermarket bakery department or different cold cuts in the delicatessen department. Those who devised the present Hungarian system of institutions chose alternative elements throughout the system of institutions. For instance, when dividing up the branches of the state, choosing and assigning powers to the so-called independent institutions (central bank, audit office, budgetary council, etc.), and setting out how judges were to be appointed. The main selection criterion was how to make their power stronger and less easy to remove. From the UK's democracy they adopted perhaps the worst characteristic, i.e., a disproportionate distribu- 
tion of mandates after general elections. The British "winner takes all" principle in single-round elections makes it almost impossible for a coalition of several opposition parties to emerge. From the US democracy, they took over the idea that supreme court members could stay in their posts for a very long time if they wished. So a constitutional court judge chosen and appointed by Fidesz would remain in his/her position and maintain loyalty to the political group which appointed him even if the opposition should win the next parliamentary elections.

Government propaganda has it that the country took politically a specifically Hungarian "third road". In truth, when the government took over, its starting point was democracy; one with many faults - more corruption and incompetence than Western democracies matured over long periods - but still a democracy. This impeded the main aim of the new power holders: to stay in power through several parliamentary terms while maintaining outward signs of democracy. They took another course: building autocracy fast and decisively. They were not taking a well-worn path, as various countries at various times arrived at autocracy in various ways. There was much improvization and many unawaited developments, but they reached full autocracy quite soon.

The Peron type of autocracy in Argentina started out from the trade-union movement, and it gained wide support by introducing regulations that benefited the workers and lower classes. By contrast, the moves of the present Hungarian variant serve to benefit the well-to-do strata of society to the detriment of the poor, the dispossessed, the handicapped, the ill and the old.

To sum up, in terms of primary and secondary characteristics (see Tables 1 and 2), my answer to the question raised in the title of this section - Is there a Hungarian hybrid? - is a decisive no. To use the reference frame of the system paradigm presented in the study, the specific Hungarian characteristics are "merely" tertiary, although by that I am not trying to belittle the notably harmful effects of the specific Hungarian form, which cause much suffering to a high proportion of the population.

\section{The Orbán system}

The socio-historical formation that has emerged in Hungary is indeed unique to the same extent only as all other socio-historical constructs. Present-day Albania, Mongolia and Vietnam are also "unique" in this sense. This statement is compatible logically with the fact that each concrete system is a historical realization of a certain type according to the criteria defined by some typology. The same type has other historical realizations as well. 
The present form of Hungarian society is a specific instance of a broader category: autocratic capitalism. Viewing this through the eyeglasses of comparative system-theory, it can be seen that Hungary's system has characteristics in common with other autocratic capitalist formations, but also attributes that distinguish it from all other countries belonging to the same type.

It is right to speak of an Orbán system. As noted in the introduction to the study, the word "system" applies to a wide variety of formations. The characteristics of Orbán's Hungary amount to a system because they affect and reinforce each other. Each serves a common purpose: to boost, solidify and render irremovable the power of its leadership and its head, Viktor Orbán.

Many aspects of the system are stamped with Orbán's personality. I am not one to belittle the effect personality traits in leading politicians have on the course of history. Their individual traits is one of the powerful factors explaining for the differences between the autocracies of Horthy, the head of the Hungarian state in the period 1920-1944, and Orbán: the two differ in social background, family and educational upbringing, military experience, system of value, culture and psyche.

In Orbán's case there has emerged a stratum of tens of thousands whom he has placed in high posts and enriched. They defend the status quo vigorously out of self-interest, not just beacuse they are loyal to their leader but to retain their power and wealth.

Once the Orbán system took shape, it began to develop its own operating mechanisms and evolutionary and selective attributes. Institutions appear or give way to others that better serve the main purpose of strengthening power. People rise to fame and power, only to fall again (usually into still cosy, well paid, but less powerful posts). More new faces appear, yet more enthusiastic and anxious to serve the leader. There is no need for central commands in lesser matters: faithful subordinates can even read their superiors' thoughts. Of course, the smooth operation of this machinery requires that all the others, the subordinates of the few thousand people grasping power in their hands, i.e. the millions of ordinary citizens accept the current situation unresistingly and silently. Their silent passivity is also a unique Hungaricum, embedded in centuries of Hungarian history. The dynamics of resignation and patience, or protest and rebellion, present researchers with politically relevant and intellectually stimulating problems, to which this study cannot extend.

Although it is quite clear to me that social formations constantly change, this study compares the types mainly through static pictures. It would be good to take things further to show the typologies of change, the types through which great social transformations occur: slow or fast, by revolutions or reforms, through shocks or in small steps, bloodily or bloodlessly. For instance, there could be compiled 
a typology for the rise and fall of great worldwide empires, from ancient times to the present day, including those of Germany, the Soviet Union or Britain.

That brings us to the difference between the approaches in two groups of disciplines: history and the modern social sciences (economics, sociology, political science). The main body of historians see historical processes as unique successions of differing situations. Only a few scholars attempt to create philosophies or theories of history. Those of Marx, Spengler and Toynbee differ strongly, but they share an aim of pinpointing regularities within the complex processes of history. Among social scientists this approach is not exceptional, but general, I could even say, mandatory. While business schools are busy with case studies, and economic historians may chart the course of a specific bank or manufacturer, most members of university departments of economics build models and introduce their students to apply them. There is no sense in discussing which discipline has the more important standard approach. Both are needed, both must remain. I hope this study will reach a few historians, especially those of them who study the contemporary period. Perhaps their ideas can also be enriched by a paradigm that recognizes alternative systems, characteristic formations and types, where they see only details of a unique and never-recurrent process.

\section{CLOSING REMARKS}

This study makes recommendations to researchers analyzing and comparing various social systems, as to how they can approach such subjects. Although inspired by experience of the post-socialist region, I am sure its underlying ideas can be applied to analyzing countries elsewhere.

I have advanced an updated version of the system paradigm described in my earlier work, as one of the possible approaches. I have discussed closely two typologies (capitalism versus socialism and democracy-autocracy-dictatorship) as two of the possible alternative typologies. My emphases convey that the paradigm and two typologies I put forward are not exclusive. In doing so I am not seeking peace or avoiding controversies, simply expressing my conviction that no single, universally applicable methodology can suffice to analyze society. No single paradigm, no single system of concepts and no single typology can claim a monopoly on solving every problem.

Let us imagine a formation of several materials with a complex structure, in a three-dimensional space. Such things are exhibited by sculptors or "visual artists."

The creation is a lively spectacle if seen from afar. That is how we sense the creation as a whole. The sight of it constantly changes as it is approached. (For 
example, we can perceive the outlines of the politico-governmental forms if only three types are distinguished, as this study has done. The picture becomes more subtle if sub-types are added to each category, or still finer distinctions are made by breaking it down into sub-sub-types.) For understanding it, there is no perfect distance between the observer and the observed artifact. All perspectives have their useful role to play.

Imagine that several spotlights have been fixed to the walls and the ceiling, each giving off light of a different color. The spectator sees the artifact differently depending on which spotlight is on and which color shines. And if the museum allows us to take various sections of the artifact, crosswise and lengthways, in all directions, again there will be various patterns to see. No view, no section offers the "true" shape. All views are "true", if the spotlight's shine is strong; all sections are "true" if studied by expert eyes.

This study had the modest aim of proposing one or two spotlights and one or two possible sections for analysts. I am open to understanding and applying other approaches and typologies as well.

\section{REFERENCES}

Acemoglu, D. - Robinson, J. A. (2012): Why Nations Fail. Danvers: Crown Publishing.

Agárdi, P. (2015): Nemzeti értékviták és kultúrafelfogások 1847-2014 (Reflections on National Values and Cultural Attitudes 1847-2014). Budapest: Napvilág Kiadó.

Ágh, A. (2016): Bánatos regionális körkép (A Pessimistic Regional Overview). Élet és Irodalom, 60(12).

Arendt, H. (1951/2004): The Origins of Totalitarianism. New York: Schocken Books.

Balog, K. (2016): An Inconsistent Triad: Trump, Sanders, Clinton, and the Radical Mismatch in the Theater of Politics. Quarks Daily, 13 June. http://www.3quarksdaily.com/3quarksdaily/2016/06/ an-inconsistent-triad-sanders-clinton-trump-and-the-radical-mismatch-in-the-theater-of-politics-by-k.html.

Bauer, T. (2016): Szabadságharc - az első lépések (War of Independence - First Steps). Manuscript. Budapest: Institute of Economics, Centre for Economics and Regional Studies, Hungarian Academy of Sciences.

Baumol, W. J. - Litan, R. E. - Schramm, C. J. (2007): Good Capitalism, Bad Capitalism, and the Economics of Growth and Prosperity. New Haven and London: Yale University Press.

Benedict, J. - Kerkvliet, T. (2015): Democracy and Vietnam. In: Coase, W. (ed.): Handbook of Southeast Asian Democratization. Abington-on-Thames: Routledge, pp. 426-441.

Bertelsmann Stiftung (2016a): Transformation Index Methodology. http://www.bti-project.org/en/ index/methodology/.

Bertelsmann Stiftung (2016b): Codebook for Country Assessments. http://www.bti-project.org/fileadmin/files/BTI/Downloads/Zusaetzliche_Downloads/Codebook_BTI_2016.pdf.

Bertelsmann Stiftung (2016c): Bertelsmann Transformation Index Country Reports. http://www. bti-project.org/fileadmin/files/BTI/Downloads/Zusaetzliche_Downloads/BTI_2016_Scores. xlsx 
Bohle, D. - Greskovits, B. (2012): Capitalist Diversity on Europe's Periphery. Ithaca and London: Cornell University Press.

Bozóki, A. (2016): Van félnivalójuk (They do have a Reason to Fear). Interview by Bita, D. - Pető, P. Népszabadság, Weekend supplement, April 9, 2016: 4.

Chen, J. - Dickson, B. J. (2008): Allies of the State: Democratic Support and Regime Support among China's Private Entrepreneurs. China Quarterly, 196: 780-804.

Corruption Research Center Budapest (2016a): Competitive Intensity and Corruption Risks. Statistical Analysis of Hungarian Public Procurement - 2009-2015. http://www.crcb.eu/wp-content/ uploads/2016/05/hpp_2016_crcb_report1_en_160513_.pdf .

Corruption Research Center Budapest (2016b): Competitive Intensity and Corruption Risks. Statistical Analysis of Hungarian Public Procurement - 2009-2015. http://www.crcb.eu/wp-content/ uploads/2016/08/crcb_2016_ijtoth_mhajdu_competitive_intensity_160820_.pdf.

Csanádi, M. (2016): China in between Varieties of Capitalism and Communism. Budapest: Institute of Economics, Centre for Economics and Regional Studies, Hungarian Academy of Sciences.

Dahl, R. A. (1983): Dilemmas of Pluralist Democracy. Autonomy versus Control. New Haven: Yale University Press.

Debreczeni, J. (2009): Arcmás (Image). Budapest: Noran Libro.

EBRD (2015a): Transition Indicators Methodology. http://www.ebrd.com/cs/Satellite?c=Content\& cid $=1395237866249 \& \mathrm{~d}=$ \&pagename $=$ EBRD $\% 2$ FContent $\% 2$ FContentLayout.

EBRD (2015b): Country-level Transition Indicators. http://www.ebrd.com/what-we-do/economicresearch-and-data/data/forecasts-macro-data-transition-indicators.html.

EBRD (2015c): Tic: Transition Indicators by Countries. www.ebrd.com/cs/Satellite?c=Content\&ci $\mathrm{d}=1395245467784 \& \mathrm{~d}=\&$ pagename $=$ EBRD $\% 2$ FContent $\% 2$ FDownloadDocument.

Freedom House (2016a): Methodology. https://freedomhouse.org/report/nations-transit-2015/methodology.

Freedom House (2016b): Nations in Transit - Country Reports. https://freedomhouse.org/report/ nations-transit-2016/nit-2016-table-country-scores.

Gedeon, P. (2014): Piac és demokrácia: Barátok vagy ellenségek? (Market and Democracy: Friends or Enemies?) Politikatudományi Szemle, 23(1): 53-76.

Hall, P. A. - Soskice, D. (eds) (2001): Variations of Capitalism and Institutional Complementarities of Comparative Advantage. Oxford: Oxford University Press.

Halmai, G. (2010): Búcsú a jogállamtól (Farewell to the Rule of Law). Élet és Irodalom, 40(29), July 22.

Hirschman, A. O. (1970): Exit, Voice, and Loyalty. Cambridge, Massachusetts: Harvard University Press.

Huang, Y. (2008): Capitalism with Chinese Characteristics. Entrepreneurship and the State. New York: Cambridge University Press.

Huntington, S. P. (1991): The Third Wave: Democratization in the Late Twentieth Century. Norman and London: University of Oklahoma Press.

Huntington, S. P. (1996): The Clash of Civilizations and the Remaking of World Order. New York: Simon and Schuster.

Kende, P. (2013): Államiság a kommunizmus után (Statehood after Communism). Bratislava: Kalligram.

King, G. - Pan, J. - Roberts, M. E. (2013): How Censorship in China Allows Government Criticism but Silences Collective Expression. American Political Science Review, 107(2): 1-18.

Kis, J. (2014): Mi a liberalizmus? (What is Liberalism?) Bratislava: Kalligram.

Kornai, J. (1980a): Economics of Shortage. Amsterdam: North Holland. 
Kornai, J. (1980b): The Dilemmas of a Socialist Economy: The Hungarian Experience. Cambridge Journal of Economics, 4(2): 147-157.

Kornai, J. (1992): The Socialist System. Princeton: Princeton University Press - Oxford: Oxford University Press.

Kornai, J. (2000): The System Paradigm. In: Schekle, W. - Krauth, W. - Kohli, M. - Elwert, G. (eds): Paradigms of Social Change. Frankfurt and New York: Campus Verlag - St. Martin's, pp. 111-133.

Kornai, J. (2006): The Great Transformation of Central and Eastern Europe: Success and Disappointment. Economics of Transition, 14(2): 207-244.

Kornai, J. (2011): Taking Stock. CESifo Forum, 12(2): 63-72.

Kornai, J. (2012): Centralization and the Capitalist Market Economy. Economics of Transition, 20(4): 569-591.

Kornai, J. (2014a): Példaképünk: Kína? (Can China Set Us an Example?) In: Kolosi, T. - Tóth, I. Gy. (eds): Társadalmi riport 2014. Budapest: TÁRKI Social Research Institute, pp. 603-616.

Kornai, J. (2014b): Threatening Dangers. Available online: http://www.kornai-janos.hu/Kornai2014 Threatening dangers.pdf. Original in Hungarian: Fenyegető veszélyek. Élet és Irodalom, 58(21), 23 May: 5.

Kornai, J. (2014c): Dynamism, Rivalry, and the Surplus Economy. Oxford: Oxford University Press.

Kornai, J. (2015): Hungary's U-turn. Journal of Democracy, 26(3): 33-48.

Körösényi, A. (2003): Political Representation in Leader Democracy. Government and Opposition, 40(3): 358-378.

Körösényi, A. (ed.) (2015): A magyar politikai rendszer-negyedszázad után (The Hungarian Political System - After Quarter of a Century). Budapest: Osiris -TÁRKI Social Research Institute.

Körösényi, A. - Patkós, V. (2015): Liberális és illiberális populizmus (Liberal and Illiberal Populism). Politikatudományi Szemle, 24(2): 29-54.

Krastev, I. - Holmes, S. (2012): An Autopsy of Managed Democracy. Journal of Democracy, 23(3): $33-45$.

Lakatos, I. (1978): The Methodology of Scientific Research Programmes. Philosophical Papers Volume 1. Cambridge: Cambridge University Press.

Langworth, R. (ed.) (2013): Churchill by Himself: The Definitive Collection of Quotations. London and New York: PublicAffairs.

Lardy, N. R. (2014): Markets over Mao: The Rise of Private Business in China. Washington, D.C.: Peterson Institute for International Economics.

Lindblom, Ch. E. (1977): Politics and Markets. The World's Political Economic Systems. New York: Basic Books.

London, J. (ed.) (2014): Politics in Contemporary Vietnam: Party, State, and Authority Relations. Houndmills, England: Palgrave-Macmillan.

Magyar, B. (2016): Post-Communist Mafia-State - The Case of Hungary. Budapest: CEU Press and Noran Libro.

Magyar, B. - Vásárhelyi, J. (eds) (2013): Magyar polip. A posztkommunista maffiaállam 1. (Hungarian Octopus: Post-Communist Mafia State. Volume 1). Budapest: Noran Libro.

Magyar, B. - Vásárhelyi, J. (eds) (2014): Magyar polip. A posztkommunista maffiaállam 2. (Hungarian Octopus: Post-Communist Mafia State. Volume 2). Budapest: Noran Libro.

Magyar, B. - Vásárhelyi, J. (eds) (2015): Magyar polip. A posztkommunista maffiaállam 3. (Hungarian Octopus: Post-Communist Mafia State. Volume 3.). Budapest: Noran Libro.

Marx, K. (1867/1990): Capital: A Critique of Political Economy. Volume I: The Process of Capitalist Production. London: Penguin Books (Penguin Classics). 
Marx, K. (1885/1992): Capital: A Critique of Political Economy. Volume II: The Process of Circulation of Capital. London: Penguin Books (Penguin Classics).

Marx, K. (1894/1992): Capital: A Critique of Political Economy, Volume III: The Process of Capitalist Production as a Whole. London: Penguin Books (Penguin Classics).

McGregor, J. (2012): No Ancient Wisdom, No Followers: The Challenges of Chinese Authoritarian Capitalism. Westport: Prosepacta Press.

Mihályi, P. (2015): A privatizált vagyon visszaállamositása Magyarországon 2010-2014 (Renationalization of Private Wealth in Hungary 2010-2014). Budapest: Institute of Economics, Centre for Economics and Regional Studies, Hungarian Academy of Sciences.

Mises, L. (1922/1981): Socialism: An Economic and Sociological Analysis. Indianapolis: Liberty.

Naughton, B. - Tsai, K. (eds) (2015): State Capitalism, Institutional Adaptation and the Chinese Miracle. New York: Cambridge University Press.

Orbán, V. (2009/2010): Megőrizni a létezés magyar minőségét (To Maintain the Hungarian Standard of Existence). http://www.fidesz.hu/hírek/2010-02-17/meg337rizni-a-letezes-magyar$\min 337$ seget $/ .{ }^{54}$

Pei, M. (2006): China's Trapped Transition: The Limits of Developmental Autocracy. Cambridge, MA: Harvard University Press.

Rainer, M. J. (ed.) (2012): Búvópatakok - a feltárás (Hidden Streams: The Excavation). Budapest: 1956 Institute.

Rainer, M. J. (ed.) (2013): Búvópatakok - széttekintés (Hidden Streams: A Survey). Budapest: 1956 Institute.

Redding, G. - Witt, M. A. (2014): China: Authoritarian Capitalism. In: Redding, G. - Witt, M. A. (eds): The Oxford Handbook of Asian Business Systems. Oxford: Oxford University Press, pp. $11-34$.

Schambaugh, D. L. (2008): China's Communist Party: Atrophy and Adaptation. Washington: University of California Press.

Schell, O. (2016): Crackdown in China: Worse and Worse. New York Review of Books, April 21: $12-16$.

Schmitt, C. (1927-1932/1996): The Concept of the Political. Chicago: University of Chicago Press.

Schumpeter, J. A. (1942/2010): Capitalism, Socialism and Democracy. London and New York: Routledge.

Sz. Bíró, Z. (2012): Oroszország: válságos évek (Russia: Critical Years). Budapest: Russica Pannonicana.

Székely-Doby, A. (2014): A kínai reformfolyamat politikai gazdaságtani logikája (Political Economic Logic of the Chinese Reform Process). Közgazdasági Szemle, 61(12): 1397-1418.

Szelényi, I. - Csillag, T. (2015): Drifting from Liberal Democracy: Neo-Conservative Ideology of Managed Illiberal Democratic Capitalism in Post-Communist Europe. Intersections. East European Journal of Society and Politics, 1(1): 18-48.

Tamás, G. M. (2005): Lassú válasz Kis Jánosnak (A Slow Answer to János Kis). Népszabadság, October 1.

Taub, A. (2016): The Rise of American Authoritarianism. Vox, March 1. http://www.vox. com/2016/3/1/11127424/trump-authoritarianism.

Tsai, K. (2007): Capitalism without Democracy: The Private Sector in Contemporary China. Ithaca: Cornell University Press.

54 The text was accessible at the time of finishing the paper (August 2016), but later disappeared from the website. 
Ungváry, R. (2014): A láthatatlan valóság (Invisible Reality). Bratislava: Kalligram.

Weber, M. (1922/2007): Economy and Society. Berkeley: University of California Press.

World Economic Forum (2016a): Appendix: Methodology and Computation of the Global Competitiveness Index 2015-2016. http://reports.weforum.org/global-competitiveness-report-20152016/appendix-methodology-and-computation-of-the-global-competitiveness-index-20152016/.

World Economic Forum (2016b): Global Competitiveness Report. http://reports.weforum.org/ global-competitiveness-report-2015-2016/.

World Economic Forum (2016c): The Global Competitiveness Index Historical Dataset, 20052015. www3.weforum.org/docs/gcr/2015-2016/GCI_Dataset_2006-2015.xlsx.

$\mathrm{Xu}, \mathrm{C}$. (2011): The Fundamental Institutions of China's Reforms and Development. Journal of Economic Literature, 49(4): 1076-1151.

Zakaria, F. (1997): The Rise of Illiberal Democracy. Foreign Affairs, November-December: 22-43.

Zakaria, F. (2014): The Rise of Putinism. Washington Post, July 31. http://www.washingtonpost. com/opinions/fareed-zakaria-the-rise-of-putinism/2014/07/31/2c9711d6-18e7-11e4-9e3b-7f2f110c6265 story.html 